\title{
Platinum Group Metal-Free Catalysts for Oxygen Reduction Reaction: Applications in Microbial Fuel Cells
}

\author{
Maida Aysla Costa de Oliveira ${ }^{1}{ }^{\mathbb{D}}$, Alessandra D'Epifanio ${ }^{1}$, Hitoshi Ohnuki ${ }^{2}$ \\ and Barbara Mecheri $1, *$ (D) \\ 1 Department of Chemical Science and Technologies; University of Rome Tor Vergata, Via della Ricerca \\ Scientifica, 00133 Rome, Italy; oliveira.maida@uniroma2.it (M.A.C.d.O.); \\ alessandra.d.epifanio@uniroma2.it (A.D.) \\ 2 Division of Marine Technology, Tokyo University of Marine Science and Technology, 2-1-6, Etchujima, \\ Koto-ku, Tokyo 135-8533, Japan; ohnuki@kaiyodai.ac.jp \\ * Correspondence: barbara.mecheri@uniroma2.it; Tel.: +39-06-7259-4488
}

Received: 8 April 2020; Accepted: 23 April 2020; Published: 26 April 2020

\begin{abstract}
Scientific and technological innovation is increasingly playing a role for promoting the transition towards a circular economy and sustainable development. Thanks to its dual function of harvesting energy from waste and cleaning up waste from organic pollutants, microbial fuel cells (MFCs) provide a revolutionary answer to the global environmental challenges. Yet, one key factor that limits the implementation of larger scale MFCs is the high cost and low durability of current electrode materials, owing to the use of platinum at the cathode side. To address this issue, the scientific community has devoted its research efforts for identifying innovative and low cost materials and components to assemble lab-scale MFC prototypes, fed with wastewaters of different nature. This review work summarizes the state-of the-art of developing platinum group metal-free (PGM-free) catalysts for applications at the cathode side of MFCs. We address how different catalyst families boost oxygen reduction reaction (ORR) in neutral $\mathrm{pH}$, as result of an interplay between surface chemistry and morphology on the efficiency of ORR active sites. We particularly review the properties, performance, and applicability of metal-free carbon-based materials, molecular catalysts based on metal macrocycles supported on carbon nanostructures, M-N-C catalysts activated via pyrolysis, metal oxide-based catalysts, and enzyme catalysts. We finally discuss recent progress on MFC cathode design, providing a guidance for improving cathode activity and stability under MFC operating conditions.
\end{abstract}

Keywords: bioelectrocatalysis; carbon nanostructures; microbial fuel cells; oxygen reduction reaction; platinum group metal-free electrodes

\section{Introduction}

The recent shortage of fossil fuels and significant influences of global warming warrant the need for eco-friendly sources of energy. Bioelectrochemical systems (BESs) have been known as the modern technology to harvest clean energy from wastewater and biomass, through the direct conversion of chemical energy stored in the organic matter present in wastewater into electricity, using the metabolism of microorganisms as a catalyst without any environmental pollution [1]. In the last decade, the efforts of the scientific community allowed improving the principles of operation and energy efficiency of this technology, followed by a reduction of costs of materials and components $[2,3]$.

Among the various types of BESs, greater attention has been focused on microbial fuel cells and enzymatic fuel cells owing to their multifunction field that combines biotic catalytic redox activity with 
conventional abiotic electrochemical reactions [4,5]. In these devices, microorganisms are responsible for catalyzing the electrochemical reactions and give a level of complexity in energy storage as compared with conventional electrochemical systems [6,7]. From this point, there is an increased interest in improving all components of BESs towards a future expansion in large scale production with high energy performance and green environmental impact [8,9]. Recent advances in microbial fuel cells have increased power production by optimizing the different microbial fuel cells components, such as using carbon and non-noble metals materials at both cathode and anode [10-12], improving cell architecture and configurations [13], and tuning the electrolyte chemistry [14-16].

However, this system still needs to achieve high performance in terms of power, activity, and long-time stability for practical applications, and the costs of the components need to be reduced [17]. On the cathode side, the oxygen reduction is one of the major challenges to be overcome, owing to the need for a high efficiency catalyst that permits a conversion of oxygen to water involving a four-electron pathway and desirable long-term stability [18]. In this context, many studies have been addressed to develop different types of catalysts based on platinum-group-metal-free (PGM-free) and metal-free catalysts to replace PGM-based materials [6,19-23].

In this review, we consider several aspects of the BES technology, with a special emphasis on the challenges and constraints for technology development. Among the different BES types, microbial fuel cells will be extensively discussed, including the most recent progress to enhance oxygen reduction reaction at the cathode side of air cathode microbial fuel cells. Much attention will be devoted to catalysts based on metal-free carbon-based materials, molecular catalysts based on metal macrocycles supported on carbon nanostructures, $\mathrm{M}-\mathrm{N}-\mathrm{C}$ catalysts activated via pyrolysis, metal oxide-based catalysts, and enzyme catalysts. We finally discuss recent progress on microbial fuel cell cathode design, providing a guidance for improving cathode activity and stability under microbial fuel cell operating conditions.

\section{Main Types of Bioelectrochemical Systems}

Bioelectrochemical systems (BESs) link a microbial metabolism to an electrochemical system and have a variety of different configurations and potential applications. All BESs have in common microorganisms as catalyst in the anode side, which transfer electrons via direct interface between biological systems and electrical circuits. By diversifying the reaction at the cathode side, several applications have been developed by utilizing this in situ current, such as direct power generation (enzymatic fuel cell (EFC) and microbial fuel cells (MFCs)), high added-value chemical production (microbial electrolysis cells (MECs) or microbial electrosynthesis (MES)), or water desalination (microbial desalination cells (MDCs)) [23].

In terms of sustainable energy harvesting, enzymatic fuel cells, microbial fuel cells, and microbial electrolysis cell are the most appropriate and promising BES types.

\subsection{Enzymatic Fuel Cells}

For all living systems, enzymes are of paramount importance because they are involved in several biochemical reactions taking place in living systems. Generally speaking, enzymes increase the reaction rate by a factor up to 10 as compared with an uncatalyzed reaction. A variety of organic and inorganic materials are oxidized through oxidizing enzymes or reduced by reducing enzymes obtaining electrical energy or high-value chemicals. As illustrated in Figure 1, enzymatic fuel cells (EFCs) directly convert chemical into electrical energy using enzymes as catalysts. The frequently used enzymes for anodic reaction are the enzyme family of oxidases and dehydrogenases [24-27]. Both enzyme families remove electrons from the substrates (glucose, alcohols, alanine, and so on) and transfer them to the anode electrode. One drawback of the oxidase family, however, is converting $\mathrm{O}_{2}$ to toxic $\mathrm{H}_{2} \mathrm{O}_{2}$ as one of the final enzymatic products and lowering the $\mathrm{O}_{2}$ level in the solution. On the other hand, use of dehydrogenases, which do not consume $\mathrm{O}_{2}$, in EFC has thus received increasing attention recently. 


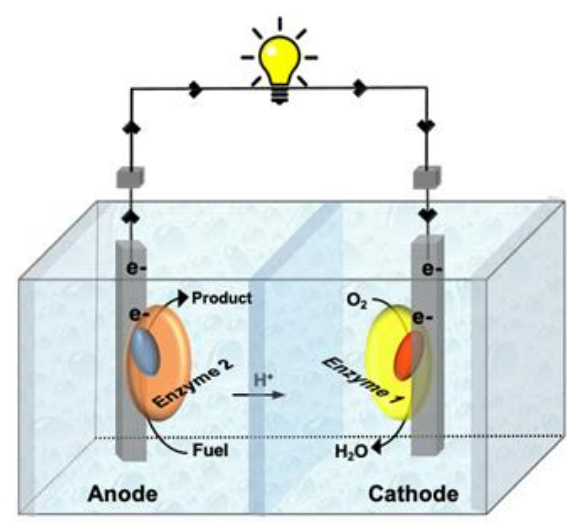

Figure 1. Schematics of an enzymatic fuel cell (EFC).

The most used enzymes for cathodic reaction are the enzyme family of multi-copper oxidases (MCOs) including bilirubin oxidase, copper efflux oxidase, and laccase [28-31]. For example, bilirubin oxidase catalyzes the oxidation of bilirubin to biliverdin and, concomitantly, four-electron reduction of $\mathrm{O}_{2}$ to $\mathrm{H}_{2} \mathrm{O}$ (direct pathway) after receiving electrons from the cathode electrode.

Likewise, MCOs catalyze the direct pathway of $\mathrm{O}_{2}$ reduction transferring electrons from the cathode to $\mathrm{O}_{2}$ molecule. For improving electron transfer, the following two methods were extensively investigated: direct electron transfer (DET) and mediated electron transfer (MET). In the DET method, electron transfer occurs directly between enzyme and electrodes. Accordingly, the enzyme active site is close enough to the electrode surface because of the DET rate decreasing exponentially with the distance. In addition, a correct orientation of enzyme is required to maintain the active site of the enzyme at the distance to achieve DET. This is because the active site of most redox enzymes is deeply buried within the protein matrix, which acts as insulator and will prevent DET. Over 1400 redox enzymes are known, but less than a hundred enzymes work in DET mode due to severe constraints. Conducting nanofibers like carbon nanotubes (CNTs) can enhance DET because their diameters range from a few to several tens of nanometers with length up to micrometers scale to facilitate electron transfer between enzymes to electrode [32,33].

As anode catalyst enzymes, glucose oxidase, fructose dehydrogenase, and cellobiose dehydrogenase have been known to incur DET. On the other hand, as cathode catalyst enzymes, the MOCs families of laccase and bilirubin oxidase have been investigated extensively on their DET properties when they catalyze the reduction of $\mathrm{O}_{2}$ to $\mathrm{H}_{2} \mathrm{O}$ coupled to the enzymatic oxidation of corresponding substrates [28]. One important point of DET-type EFC is that the output voltage is controlled by the redox potential of enzyme's active site, which electrically communicates with each electrode, and accordingly, a set of a cathodic enzymes with a negative redox potential and an anodic enzyme with positive redox potential is preferable. In the MET method, additional redox active compounds such as ferrocene derivatives, 2, 2' -azinobis(3 ethylbenzothiazolin-6-sulfronate (ABTS), and cyano-metal complexes $\left(\left[\mathrm{Fe}(\mathrm{CN})_{6}\right]^{3-/ 4-},\left[\mathrm{Os}(\mathrm{CN})_{6}\right]^{3-/ 4-},\left[\mathrm{W}(\mathrm{CN})_{8}\right]^{3-/ 4-}\right.$, and $\left.\left[\mathrm{Mo}(\mathrm{CN})_{8}\right]^{3-/ 4-}\right)$ are used as a diffusive redox mediator to shuttle electrons between the active site of enzymes and electrode surface [26,34-37]. In this case, the enzyme catalyzes the oxidation or reduction of the mediator, which is regenerated on the electrode. Thus, the mediator must have chemically stable oxidized and reduced forms [38].

Redox polymers have been also extensively used as non-diffusive mediators that are attached along with enzymes and on electrodes [39,40]. Polymer structures such as are polyvinylimidazole, polyallylamine, and polyvinylpyridine as the backbone and osmium or ruthenium complexes as the redox centers have been widely investigated. To improve the catalytic efficiency of redox polymer, the electron-hopping along the chain or between the chains is a key factor. Most of enzymes are not able to perform a DET process, while many EFC systems use the MET method. It is notable that a large increase in current density can be obtained by MET, but an unavoidable thermodynamic loss is 
incurred; in fact, the mediators require a potential shift from that of the enzyme's active site to induce electron transfer.

One of the major drawbacks of EFCs is limited long-term stability, which is caused by denaturation or conformational change of enzymes. The immobilized enzymes on an electrode can be active for a few weeks, but it is still short as a part of real application devices [41]. Significant progresses on the lifetime extension have been made by encapsulation of the enzyme in micelles or polymer layer, which physically confines the enzymes to prevent denaturation [42], or utilizing the enzymes from thermophillic microorganisms, which are more stable under a wide range of experimental conditions [43].

\subsection{Microbial Fuel Cells (MFCs)}

Differently from EFCs, MFCs directly convert chemical into electrical energy using microorganisms as catalysts, which can either be located in both the anode and cathode, or only the anode or only the cathode [4]. There are several designs of MFC currently being used, dual or two-chamber MFC and single chamber MFC (Figure 2).

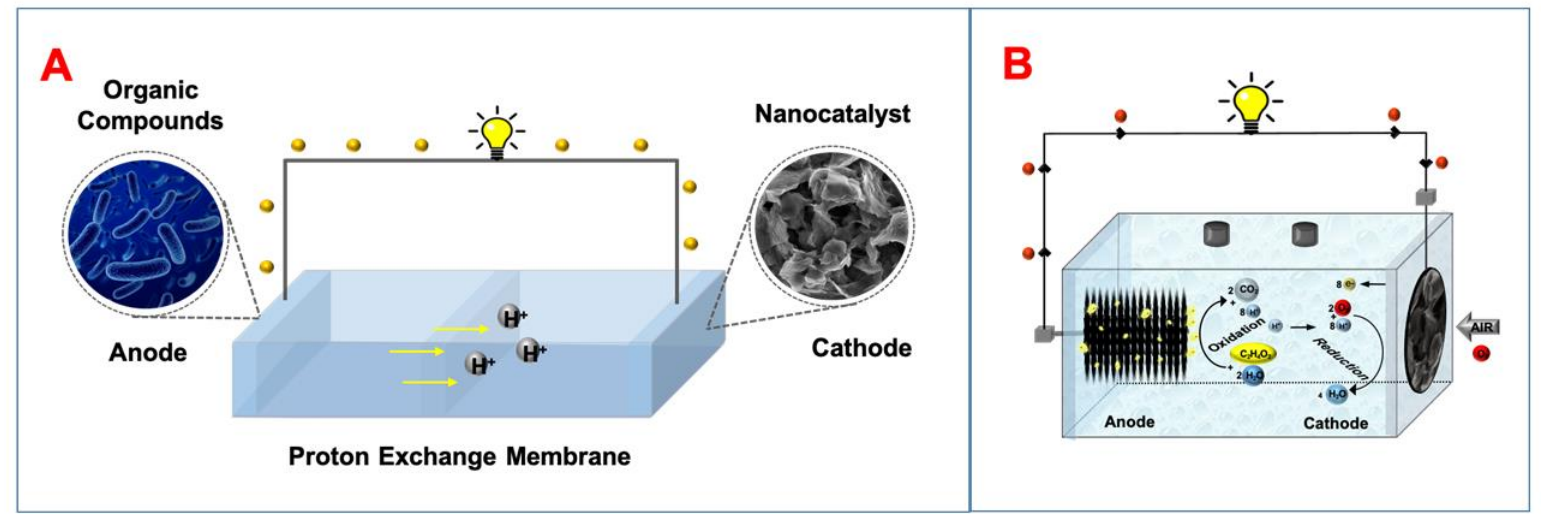

Figure 2. Schematic diagram of a two-chamber microbial fuel cell (MFC) (A) and a single-chamber MFC (B).

A two-chamber MFC generally consists of an anode (in this case, a bio-anode, where the microbes act as catalysts), a cathode (also called the air cathode, as it has direct contact with the oxygen in the atmosphere), and an electrolyte (such as a polymer membrane). Exoelectrogen microorganisms (i.e., having the capability to transfer electrons extracellularly) can be in one or both compartments to degrade organic matter (called substrates) via their metabolisms (Figure 2A). Then, electrons are produced at the anode and transferred through an external circuit to the cathode, while a charge balancing number of cations and anions are transferred between the anode and cathode. A single-chamber MFC contains only one vessel in which both anode and cathode electrodes reside, and substrate is filled into the vessel (Figure 2B). A single-chamber MFC was first demonstrated by Zeikus and Park, who developed an $\mathrm{Fe}^{3+}$ graphite cathode with an internal proton-permeable porcelain layer [44,45]. Years later, Liu and Logan assembled an oxygen-permeable air cathode membrane suitable for single-chamber MFCs, and these cell configurations are now the most widely used. In this system, cathode catalysts (i.e., platinum or platinum group metal catalysts) are supported on a carbon-cloth electrode and are in direct contact with an electrolyte. An air-cathode system can also be equipped with a polymer membrane, to avoid electrolyte leakages through the cathode promoted by hydrostatic pressure. Electrolyte leakages can also be minimized by applying coatings, such as polytetrafluoroethylene (PTFE), to the outside of the cathode (diffusion layer), allowing oxygen diffusion, but limiting bulk water loss [46]. On the other hand, oxygen diffusion into the anode chamber needs to be controlled, for the use of oxygen as final acceptor of microbial metabolism in the anode chamber leads to a decrease of Coulombic efficiency, which is defined as the fraction of electrons recovered as the current versus maximum recovery. 


\section{Oxygen Reduction Reaction at the Cathode Side of MFCs: Electrode Kinetics and Electrocatalysis}

MFC performance still needs to be improved for practical applications, as the costs of the materials are high. Related to the prototype costs, the cathode accounts for about $50 \%$ of the total cost of the cell, owing to the use of expensive catalysts for accelerating the sluggish kinetics of the oxygen reduction $[47,48]$.

Oxygen as a final electron acceptor in an air-cathode MFC is an ideal choice, but the high activation energy $\left(498 \mathrm{~kJ} \mathrm{~mol}^{-1}\right)$ to break the $\mathrm{O}=\mathrm{O}$ bond requires the use of a catalyst [49]. The nature of the catalyst and the operating conditions, such as $\mathrm{pH}$, affect oxygen reduction reaction (ORR) pathways; indeed, ORR occurs as a multi-step reaction via either a four-electron pathway or a two-electron pathway [50], as illustrated in Table 1. To gain maximum energy from the reaction, the catalyst should support a mechanism involving a direct four-electron pathway or involving two steps of a two-electron pathway; by contrast, the peroxide production should be avoided, for it causes a decrease of voltage efficiency in terms of operating potential and promotes degradation of fuel cell components [50,51].

Table 1. Oxygen reduction reaction (ORR) mechanisms in acidic and alkaline media.

\begin{tabular}{cccc}
\hline $\mathbf{p H}$ & Pathway & Reactions & E $^{\mathbf{0}}$ vs. $_{\text {RHE }}^{\mathbf{1}}$ \\
\hline$<7$ & Direct four-electron & $\mathrm{O}_{2}+4 \mathrm{H}^{+}+4 \mathrm{e}^{-} \rightarrow 2 \mathrm{H}_{2} \mathrm{O}$ & 1.230 \\
$<7$ & two-electron & $\mathrm{O}_{2}+2 \mathrm{H}^{+}+2 \mathrm{e}^{-} \rightarrow \mathrm{H}_{2} \mathrm{O}_{2}$ & 0.695 \\
$<7$ & - & $\mathrm{H}_{2} \mathrm{O}_{2}+2 \mathrm{H}^{+}+2 \mathrm{e}^{-} \rightarrow 2 \mathrm{H}_{2} \mathrm{O}$ & 1.776 \\
$>7$ & Direct four-electron & $\mathrm{O}_{2}+2 \mathrm{H}_{2} \mathrm{O}+4 \mathrm{e}^{-} \rightarrow 4 \mathrm{OH}^{-}$ & 1.230 \\
$>7$ & two-electron & $\mathrm{O}_{2}+\mathrm{H}_{2} \mathrm{O}+2 \mathrm{e}^{-} \rightarrow \mathrm{H}_{2} \mathrm{O}^{-}+\mathrm{OH}^{-}$ & 0.695 \\
$>7$ & - & $\mathrm{H}_{2} \mathrm{O}^{-}+\mathrm{H}_{2} \mathrm{O}+2 \mathrm{e}^{-} \downarrow \mathrm{OH}^{-}$ & 1.776 \\
\hline
\end{tabular}

${ }^{1}$ RHE: reversible hydrogen electrode.

The oxygen reduction kinetics on various electrocatalysts was investigated using a rotating ring-disk electrode (RRDE) and rotating disk electrode (RDE) setup to measure current density, and overpotential for ORR.

Insights on ORR mechanisms have been achieved by evaluating the number of electrons exchanged during the reaction, and such a number is generally evaluated or calculated using two different approaches [52,53].

By applying the Koutecky-Levich (K-L) theory, it is possible to separate kinetic and diffusional contributions to the measured current through Equation (1):

$$
\frac{1}{\mathrm{I}}=\frac{1}{\mathrm{I}_{\mathrm{K}}}+\frac{1}{\mathrm{I}_{\mathrm{L}}}=\frac{1}{\mathrm{I}_{\mathrm{K}}}+\frac{1}{0.62 \mathrm{nFAD} D^{2 / 3} v^{1 / 6} \mathrm{C} \omega^{1 / 2}}
$$

where $I$ is the measured current and $I_{\mathrm{K}}$ and $I_{\mathrm{L}}$ are the kinetic-limited and mass transfer-limited current, respectively. As also indicated in Equation (1):, $I_{\mathrm{L}}$ is proportional to the square root of angular velocity $(\omega)$ of the RDE, through the Faraday constant $(\mathrm{F})$, the electrode area (A), the diffusion coefficient of the reactant $(D)$, the kinematic viscosity of the electrolyte $(v)$, and the concentration of the reactant in the bulk electrolyte (C). From here, the electron number (n) can be deduced from the slope of the linear plot of the inverse of current $\left(i^{-1}\right)$ versus the inverse of the square root of the electrode rotation rate $\left(\omega^{-1 / 2}\right)$, named the Koutecky-Levich plot [53,54].

Although the $\mathrm{K}-\mathrm{L}$ theory is fine, previous reports explicitly indicated that the $\mathrm{K}-\mathrm{L}$ method is not suitable to determine $\mathrm{n}$ for the ORR either theoretically or experimentally [55]. It is generally considered more appropriate and less speculative to evaluate the number of electrons transferred in ORR by RRDE tests [56]. 
With the RRDE setup, hydrogen peroxide produced during ORR is oxidized at a Pt ring, and by separately measuring the ring and disk current, it is possible to quantify the hydrogen peroxide yield (Equation (2)):

$$
\% \mathrm{H}_{2} \mathrm{O}_{2}=\frac{200 \times \frac{I_{\text {ring }}}{N}}{I_{\text {disk }}+\frac{I_{\text {ring }}}{N}}
$$

where $\mathrm{N}$ is the collection efficiency (theorical number related to the electrode).

The number of electrons transferred (n) can be thus calculated from Equation (3):

$$
n=\frac{4 \times \frac{I_{\text {ring }}}{N}}{I_{\text {disk }}+\frac{I_{\text {ring }}}{N}}
$$

Detailed studies using either the RDE or RRDE technique have demonstrated the role of $\mathrm{pH}$ in affecting ORR mechanisms. An investigation of ORR mechanisms on Pt and non-Pt surfaces indicated that, in an acidic environment, the adsorption of hydroxide species, resulting from water activation, inhibits $\mathrm{O}_{2}$ adsorption on active sites. Differently, in an alkaline environment, the adsorption of hydroxide species, resulting from a specific adsorption of $\mathrm{OH}$ groups, not only inhibits $\mathrm{O}_{2}$ adsorption (as in the case of $\mathrm{Ph}<7$ ), but also favors an outer-sphere electron transfer mechanism, leading to peroxide as the product [56]. The absence of this outer-sphere mechanism at $\mathrm{pH}<7$ imposes the need for using ORR electrocatalysts based on $\mathrm{Pt}$, while the use of non-Pt surfaces in alkaline media allowed achieving high ORR performance. By tuning the surface chemistry and morphology of non-noble metal catalyst surfaces, it is possible to boost the inner-sphere electron transfer mechanism in alkaline media by favoring the $\mathrm{O}_{2}$ adsorption and promoting a four-electron transfer process. Atanassov et al. studied the role of $\mathrm{pH}$ on ORR at the surface of Fe-based catalysts, and found the occurrence of a mechanism shift that takes place at $\mathrm{pH}=7$, resulting from variations in the structure of the electrical double-layer structure and the reaction mechanism [57]. By analyzing the changes in kinetic current density and the number of electrons exchanged, it was possible to conclude that ORR is faster in an acidic environment, thanks to a solely inner-sphere electron transfer process, which leads to a four-electron mechanism; at $\mathrm{pH}=7$, this mechanism shifts to contributions from both inner and outer-sphere electron transfer mechanisms, leading to a decrease in the number of electrons exchanged from 3.77 at $\mathrm{pH}=1$ to 2.38 at $\mathrm{pH}=13.7$.

Double layer capacitance (Cdl) and specific capacitance $(\mathrm{Cs})$ are important parameters related to the structure of the electrical double layer and the surface area of the electrode [58], and they are usually evaluated to get insights on the effect of the catalyst on ORR. Cdl values can be obtained from cyclic voltammetry (CV) measurements in $\mathrm{N}_{2}$-saturated electrolytes, in the absence of any faradic process. $\mathrm{Cdl}$ is thus estimated by plotting the current as a function of potential scan rate (v) at a fixed overpotential in the region where mostly a capacitive behaviour takes place, with Cdl being the slope of the linear regression line (Equation (4)).

$$
\mathrm{I}=\mathrm{Cdl} \times \mathrm{v}
$$

The specific capacitance (Cs) can be also estimated by integrating CV curves in an $\mathrm{N}_{2}$-saturated atmosphere, in an $E_{2}-E_{1}$ potential window, as indicated in Equation (5) [59]:

$$
\mathrm{Cs}=\int_{\mathrm{E}_{1}}^{\mathrm{E}_{2}} \mathrm{i}(\mathrm{E}) \mathrm{dE}=2\left(\mathrm{E}_{2}-\mathrm{E}_{1}\right) \mathrm{mv}
$$

where $C s$ is the specific capacitance, $E_{1}$ and $E_{2}$ are the cut-off potentials in cyclic voltammetry, $i(E)$ is the measured current, $\mathrm{m}$ is the mass of catalyst on the electrode surface, and $\mathrm{v}$ is the potential scan rate.

Complementarily to electrochemical characterization, other analytic methods, as X-ray absorption spectroscopy, Mössbauer spectroscopy, X-ray photoelectron spectroscopy (XPS), and Raman spectroscopy, provide information about the catalyst surface chemistry and structural defects, 
respectively. Moreover, Brunauer-Emmett-Teller (BET) surface area analysis, scanning electron microscopy (SEM), atomic force microscopy, and transmission electron microscopy (TEM) allow achieving insights into catalyst morphology. This combined characterization allows evaluating catalyst performance by simulating operational conditions and selecting the best catalyst material for test in a complete system [60-62].

Platinum nanoparticles supported on high surface area carbon $(\mathrm{Pt} / \mathrm{C})$ still represent the state-of-the-art catalyst to drive oxygen reduction through a direct $4 \mathrm{e}^{-}$mechanism at the cathode side of BESs. However, the high cost of platinum and limited resources hinders practical application in BESs, beyond its low long-term durability owing to the poisoning $[63,64]$. Therefore, finding alternative catalysts to replace Pt-based catalysts is indispensable for scaling up MFC technology in waste treatment scenarios and energy recovery [20,22]. Several methods have been developed for producing catalyst materials as an alternative to platinum-metal-group (PGM). Materials obtained by combining nanostructured carbon and non-precious transition metals, recently classified as PGM-free catalysts, are the best candidate to replace expensive PGMs.

\section{Oxygen Reducing Catalysts Based on Platinum Group Metal-Free Materials}

PGM-free catalysts are mostly based on a nitrogen-containing carbon matrix with atomically dispersed particles of a transition metal such as iron, manganese, cobalt, and nickel [65-67]. Carbon substrates include graphene, graphene oxide, carbon black, carbon nanotubes, carbon nanofibers, and biochar. Heteroatom-doping with nitrogen, phosphorus, and sulphur allows introducing defects on a graphitic-like structure. Artyushkova et al. have shown that a direct four-electron transfer mechanism only occurs in the case of transition metal coordinated with nitrogen; otherwise, the mechanism involves $2 \times 2$-electron transfer [68].

Among PGM-free catalysts, M-N-C (metal-nitrogen-carbon) [63], TMO (transition metal oxide) [69], and activated carbon (metal-free) catalysts [70] can be considered the most representative of the series of best performing materials. Figure 3 schematically represent the three classes of PGM-free catalysts, which will be reviewed and discussed in detail below.

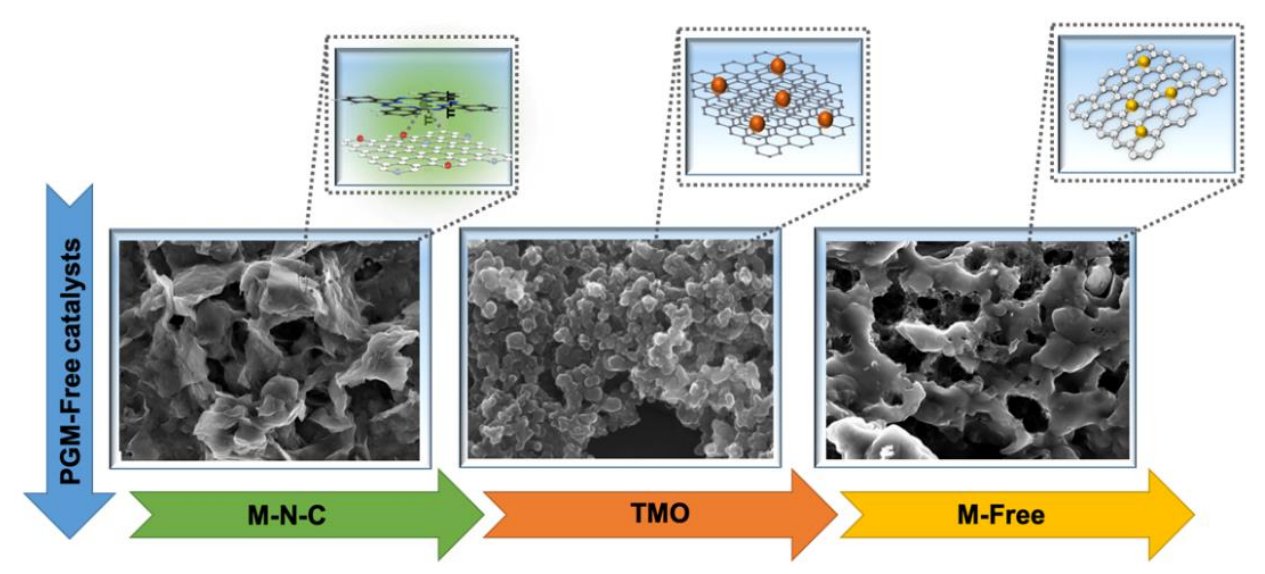

Figure 3. Schematic illustration of M-N-C catalysts, transition metal oxide (TMO) catalysts, and activated carbon catalysts, with typical scanning electron microscopy (SEM) images. PGM, platinum group metal.

\subsection{Transition Metal-Nitrogen-Carbon (M-N-C) Catalysts}

Transition metal-nitrogen-carbon (M-N-C) catalysts are obtained by combining different sources of a transition metal, nitrogen, and carbon. They can be easily synthetized using inexpensive precursors, as a different carbon substrate, nitrogen-containing compounds, organic polymers, and transition metal sources [55]. 


\subsubsection{Pyrolyzed Catalysts}

Pyrolyzed catalysts can be easily synthesized by combining transition metal salts, nitrogen-rich organic precursors, and carbon sources followed by pyrolysis steps. Among the different transition metals, iron has received much attention owing to its low environmental impact and high ORR activity. The efficiency of active sites in Fe-N-C catalysts is ascribed to Fe- $\mathrm{N}_{\mathrm{x}}$ structures (where the central iron cation is coordinated to $x$ nitrogen atoms $(x \sim 4))$, which directly catalyze the reduction of molecular oxygen to water via the four-electron mechanism. Previous investigations based on ${ }^{57} \mathrm{Fe}$ Mössbauer spectroscopy, X-ray absorption spectroscopy, and density functional theory on Fe-N-C electrocatalysts identified FeNx moieties mainly in Fe(II) low-spin and Fe(III) high-spin states [71-74]. The temperature of pyrolysis is crucial for Fe-N coordination and catalytic stability; metal-nitrogen coordination improves up to $600-700{ }^{\circ} \mathrm{C}$, while a higher temperature may cause a detrimental effect, as previous reported [75,76]. In addition, iron content is also as key factor to tune ORR activity. While a low iron content in the precursors results in a low density of $\mathrm{FeN}_{4}$ sites, a high Fe content leads to clustering of Fe atoms and causes the formation of inactive Fe clusters and/or nanoparticles, as demonstrated by advanced electron microscopy studies [77].

Surface area and porosity of the F-N-C catalysts is also of paramount importance to boost ORR activity. Highly porous $3 \mathrm{D}$ hierarchical $\mathrm{Fe}-\mathrm{N}_{4}$ composites have demonstrated good activity in terms of oxygen reduction and long-term stability thanks to the synergistic effect of the high concentration of active sites and a porous 3D hierarchical structure, which favours mass transfer [78-80]. Moreover, Chen et al. have proposed a highly porous 3D Fe-N-C catalyst based on single-metal-site zeolitic imidazolate framework with ORR activity as high as that of current state-of-the-art $\mathrm{Pt} / \mathrm{C}$ taken as control [81]. In fact, the use of multiple-step annealing high-temperature treatments on metal organic frameworks leads to catalyst with good conductivity, avoiding agglomerations of carbon matrix [82].

Along with iron salts, iron macrocycles such as iron phthalocyanines ( $\mathrm{FePc}$ ) have been explored as iron sources, as a self-supported catalyst and/or a simultaneous source of carbon, nitrogen, and iron. Thanks to the composition of these metal macrocycles, it is possible to obtain a catalyst with high surface area and high active site density [83-85].

Zhang et al. showed that Fe(II)Pc supported on carbon black exhibits high performance toward ORR owing to the interaction of catalyst with support, which modulates electronic properties through the delocalized $\pi$-electron cloud [86]. Many studies have been performed to elucidate the role of supporting FePc on graphene, graphene oxide, and nitrogen-doped graphene; by tuning the surface chemistry and morphology of the support, it is possible to promote metal stabilization through $\pi-\pi$ interaction, resulting in good ORR activity and durability in neutral media [87-91]. Osmieri et al. have developed different pyrolyzed $\mathrm{MePc}(\mathrm{Me}=\mathrm{Fe}, \mathrm{Co}, \mathrm{Mn}$, and $\mathrm{Zn}$ ) as ORR catalysts. As compared with cobalt, copper, and zinc, iron showed a superior catalytic activity towards ORR performance involving a direct four-electron transfer mechanism [92]. In addition, through a hard template method as a synthesis strategy, ORR catalytic activity can be further enhanced [83,84].

As far as nitrogen sources are concerned, Santoro et al. presented a variety of electrochemical studies of Fe-N-C catalysts obtained using different nitrogen-rich organic precursors, including benzimidazole and nicosamide. The obtained catalysts have shown a very high catalytic activity toward ORR in neutral media, involving a very close to four-electron transfer during ex situ experiments and in microbial fuel cells devices [21,93-95].

Table 2 shows a summary of the MFC performance (power density) of M-N-C catalysts obtained by different sources of carbon, iron, and nitrogen, and different pyrolysis treatments. 
Table 2. Summary of the microbial fuel cell (MFC) performance (power density, PD) of M-N-C catalysts obtained by different sources of carbon, iron, and nitrogen, and different pyrolysis treatments.

\begin{tabular}{|c|c|c|c|c|c|}
\hline Carbon Source & Iron Source & $\begin{array}{l}\text { Nitrogen } \\
\text { Source }\end{array}$ & Pyrolysis T & PD & Ref. \\
\hline $\begin{array}{l}\text { Benzimidazole, } \\
\text { Aminobenzimidazole }\end{array}$ & $\mathrm{Fe}\left(\mathrm{NO}_{3}\right)_{3}$ & $\begin{array}{l}\text { Benzimidazole, } \\
\text { Aminobenzimidazole }\end{array}$ & $900^{\circ} \mathrm{C}$ & $1620 \mathrm{mWm}^{-2}$ & [95] \\
\hline Ketjen Black & $\begin{array}{l}\text { ClFeTMPP, } \\
\text { FePc }\end{array}$ & $\mathrm{NH}_{3(\mathrm{~g})}$ & $700^{\circ} \mathrm{C}$ & $590 \mathrm{mWm}^{-2}$ & [96] \\
\hline Aminoantipyrine & $\mathrm{Fe}\left(\mathrm{NO}_{3}\right)_{3}$ & Aminoantipyrine & $950^{\circ} \mathrm{C}$ & $2510 \mathrm{mWm}^{-2}$ & [97] \\
\hline Graphene & $\mathrm{Fe}_{2} \mathrm{O}_{3}$ & Pyrrole & $600^{\circ} \mathrm{C}$ & $1380 \mathrm{mWm}^{-2}$ & [98] \\
\hline Activated carbon & $\mathrm{FeCl}_{3}$ & Chitosan & $800^{\circ} \mathrm{C}$ & $2400 \mathrm{mWm}^{-2}$ & [99] \\
\hline Graphene oxide & $\mathrm{Fe}_{2} \mathrm{O}_{3}$ & BNNS $^{1} \mathrm{~s}$ & $550^{\circ} \mathrm{C}$ & $1673 \mathrm{mWm}^{-2}$ & {$[100]$} \\
\hline 2-methylimidazole & $\mathrm{FeCl}_{2}$ & 2-methylimidazole & $800^{\circ} \mathrm{C}$ & $4335 \mathrm{mWm}^{-2}$ & [101] \\
\hline Aminoantipyrine & $\mathrm{Fe}\left(\mathrm{NO}_{3}\right)_{3}$ & Aminoantipyrine & $950^{\circ} \mathrm{C}$ & $1300 \mathrm{mWm}^{-2}$ & [102] \\
\hline Nicarbazin & $\mathrm{Fe}\left(\mathrm{NO}_{3}\right)_{3}$ & $\begin{array}{c}\mathrm{NH}_{3(\mathrm{~g})}, \\
\text { Nicarbazin }\end{array}$ & $900^{\circ} \mathrm{C}$ & $1850 \mathrm{mWm}^{-2}$ & [103] \\
\hline Activated carbon & $\mathrm{Fe}(\mathrm{II}) \mathrm{Pc}$ & $\mathrm{Fe}(\mathrm{II}) \mathrm{Pc}$ & $900^{\circ} \mathrm{C}$ & $1092 \mathrm{mWm}^{-2}$ & {$[104]$} \\
\hline Phenolic resin & $\mathrm{Fe}(\mathrm{II}) \mathrm{Pc}$ & $\mathrm{Fe}(\mathrm{II}) \mathrm{Pc}$ & $600^{\circ} \mathrm{C}$ & $330 \mathrm{mWm}^{-2}$ & [75] \\
\hline Activated carbon & $\mathrm{Fe}(\mathrm{II}) \mathrm{Pc}$ & $\mathrm{Fe}(\mathrm{II}) \mathrm{Pc}$ & $400-1000^{\circ} \mathrm{C}$ & $120 \mathrm{mWm}^{-2}$ & [76] \\
\hline $\begin{array}{l}\text { Ricobendazole, } \\
\text { niclosamide }\end{array}$ & $\mathrm{Fe}\left(\mathrm{NO}_{3}\right)_{3}$ & $\begin{array}{l}\text { Ricobendazole, } \\
\text { niclosamide }\end{array}$ & $975^{\circ} \mathrm{C}$ & $2510 \mathrm{mWm}^{-2}$ & [21] \\
\hline
\end{tabular}

${ }^{1}$ BNNS: Boron nitride nanosheets.

\subsubsection{Molecular Catalysts}

Along with energy conversion, ORR is also essential for life processes, such as biological respiration. Because this reaction is catalyzed by iron porphyrins in cytochromes, mimicking the efficiency of biological systems has inspired the current research on ORR catalysts towards the use of metal complexes of porphyrinoids. Since the first demonstration that cobalt phthalocyanines can reduce molecular oxygen [105], different metal complexes of phthalocyanines, porphyrins, and corroles have been investigated as catalysts in ORR [106-109].

Electrocatalysis of ORR at the surface of molecular catalysts is generally controlled by the metal center and ligand interactions $[110,111]$.

Among the different metal macrocycles, $\mathrm{Fe}-\mathrm{N}_{4}$ systems supported on carbon materials have shown a good performance for oxygen reduction in air-cathode MFC [112]. The intrinsic activity of Fe- $\mathrm{N}_{4}$ sites is beneficial to ORR through the synergistic effects between $\mathrm{Fe}-\mathrm{N}_{4}$ moieties and their interaction with carbon support [113]. Catalytic activity is not only the result of the $\mathrm{Fe}-\mathrm{N}_{4}$ complex interaction, but also carbon substrate properties, such as the adjustable surface area and chemical structure, which are crucial to keep the macrocycle structure open, avoiding the aggregation phenomena, and consequently providing a high density of active sites for the oxygen reduction. Interestingly, the development of $\mathrm{Fe}-\mathrm{N}_{4}$ catalyst involves low cost synthesis processes, contributing to reducing the overall MFC cost. Oliveira et al. have shown a high performing electrocatalyst in a single chamber microbial fuel cell with a maximum power density of $295 \mathrm{mWm}^{-2}$. The catalyst was obtained by electrochemical exfoliation of graphite to produce graphene oxide as substrate to support an FePc macrocycle [20]. Successively, the same research group have improved the activity of graphene oxide support by adding nitrogen functionalities via a single step nitrogen doping solution process. They have demonstrated that the catalyst has not only high catalytic activity, but also a long lifetime [63]. In fact, FePc supported on graphene oxide is stabilized through $\pi$-stacking, allowing comparable activity and higher long-term stability as compared with the $\mathrm{Pt} / \mathrm{C}$ catalyst $[20,114]$.

Yang et al. have used multi-wall carbon nanotubes (MWNTSs) to support FePc. The hybrid catalyst with a well-defined nanostructure achieved a power density of $185 \mathrm{mWm}^{-2}$, and excellent durability, suggesting that the $\mathrm{Fe}-\mathrm{N}_{4}$ on MWNTs significantly changes the geometry and electronic structure of the Fe-complex, owing to $\pi-\pi$ interactions [115]. Chung et al. added the relevance of synthesis temperature to the study of molecular catalysts. A low-temperature annealing treatment was 
found to be suitable for maintaining the Fe-N-C structure in contact with carbon nanoribbons. Indeed, this two-dimensional catalyst showed higher ORR activity than the $\mathrm{Pt} / \mathrm{C}$ catalyst [80].

The effect of the type of carbon support on the catalytic activity of FePc was also investigated [116,117]. The content of pyridinic nitrogen on the carbon structure was identified as an important parameter to boost ORR [118]. By supporting FePc on either carbon black or carbon black pearls, oxygen reduction to water involves a mechanism of four-electron transfer [119]. When assembled at the cathode side in an MFC device, long-term operation depends on cathode morphology, which can be tuned by hot pressing. The optimized cathode allowed achieving a power density of $206 \mathrm{mWm}^{-2}$, higher than that of the Pt/C cathode after 100 days of MFC operation [64].

There are still open issues that need to be addressed before the widespread application of molecular catalysts in energy conversion devices, such as durability and reaction kinetics. In fact, molecular catalysts, in their intrinsic nonpyrolyzed form, have shown lower activity and stability as compared with the corresponding pyrolyzed form, but the improvement made recently supports their applicability. This is particularly evident for microbial fuel cells, where the operating conditions are mild (circumneutral $\mathrm{pH}$ and room temperature) and the reduction of materials cost is mandatory to support the sustainability of this technology. In fact, avoiding any pyrolysis step allows not only a higher control on the active site structure, but also a cost reduction for materials synthesis.

Figure 4 summarizes the power density performance of different molecular catalysts based on iron supported on different carbon substrates assembled at the cathode side of MFC devices. In particular, Figure 4A schematically shows ORR at the surface of a molecular catalyst, Figure $4 \mathrm{~B}$ shows the polarization and power density curves of an MFC equipped with a typical Fe-N-C at the cathode side, and Figure 4C shows the different MFC performance of Fe-N-C molecular catalysts in terms of maximum power density. All the catalysts shown in Figure $4 \mathrm{C}$ have high activity in a neutral environment, FePc on $\mathrm{BP}\left(\mathrm{NH}_{3}\right), \mathrm{CTNs}$, and polyindole(PID)/CTNs allow achieving the highest power densities.

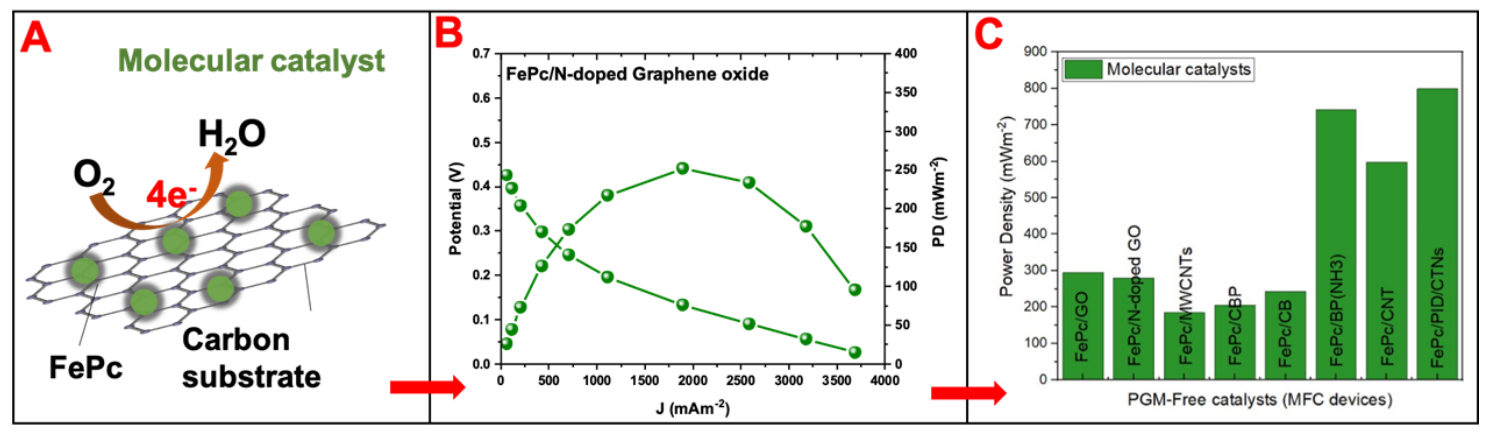

Figure 4. (A) Schematics of oxygen reduction reaction (ORR) at the surface of a molecular catalyst; (B) polarization and power density curves of FePc on N-doped graphene oxide in a single-chamber MFC; (C) MFC performance (maximum power density) of different types of molecular catalysts.

\subsection{Transition Metal Oxides (TMOs)}

Among PGM-free catalysts, transition metal oxides have also been exploited for oxygen reduction reaction in MFC devices. It is owing to their properties such as structural diversity, electrochemical activity, and ease of doping. In addition, TMOs can be combined with conductive carbon materials as an approach to improve the electronic conductivity of the catalyst. Hannah Osgood and co-workers have synthesized different TMOs $\left(\mathrm{Fe}^{2+/ 3+}, \mathrm{Co}^{2+/ 3+}, \mathrm{Mn}^{3+/ 4+}\right.$, and $\left.\mathrm{Ni}^{3+/ 4+}\right)$ and evaluated the effect of structure on ORR activity [120]. Electrochemical conductivity has been also identified as a key factor to enhance ORR performance. Along combining TMOs with carbon support, electrical conductivity can be improved by introducing defects in the matrix (dopants or electronic structures) [121]. The importance of crystallite size and morphology on ORR performance was discussed by Goswami et al., studying cobalt oxides, copper oxides, manganese oxides, and iron oxides combined with different types of conductive 
materials like carbon nanotubes, carbon nanofibers, mesoporous carbon, and graphene [122]. Sun and co-workers developed different TMOs (FeOx, MnOx, and $\mathrm{CoOx}$ ) on graphene oxide, demonstrating that ORR performance and mechanisms are structure-dependent [123]. Seonghee et al. have synthetized three N-doped carbon/TMO (Fe, Co, Ni) catalysts by the plasma process and studied its electrochemical behaviour toward ORR. The catalyst containing iron oxide exhibited the best catalytic activity, and this can be attributed to the coordination of Fe cations with graphitic nitrogen and pyridinic nitrogen, increasing oxygen reduction activity [124]. A nanocomposite catalyst based on cobalt oxide and nitrogen-doped graphene was also prepared and assembled at the cathode side of an MFC. The catalyst had long-term stability in neutral electrolyte and achieved a power density of $1340 \mathrm{mWm}^{-2}$, very close to that achieved with $\mathrm{Pt} / \mathrm{C}$ assembled on air-cathode MFC [125].

Among the different TMOs, manganese oxides have received much attention from the scientific community. $\mathrm{MnO}_{2}$ with a cryptomelane-type octahedral molecular sieve (OMS-2) structure was assembled at the cathode side of an MFC, exhibiting good catalytic performance towards oxygen reduction reaction (ORR) with a power density of $165 \mathrm{mWm}^{-2}$ [126]. $\alpha-\mathrm{MnO}_{2}$ nanorods supported on $\mathrm{N}$-doped reduced graphene were also obtained via the hydrothermal method involving only one step of synthesis. The prepared catalyst showed an electrochemical performance producing a maximum power density of $135 \mathrm{mWm}^{-2}$ in MFCs [127]. In addition, multivalent MnOx supported on two different hybrid carbon materials, as nitrogen-doped carbon and reduced graphene oxide, was also prepared and characterized. The catalytic activity toward oxygen reduction in neutral media was higher for MnOx supported on $\mathrm{N}$-doped carbon than reduced graphene oxide owing to the interplay of surface chemistry and morphology of the resulting composite catalyst. Additionally, the catalyst has a high performance when assembled in an MFC cathode, with a power density maximum of $467 \mathrm{mWm}^{-2}$, higher than $\mathrm{Pt} / \mathrm{C}$ as the control [128]. A bimetallic Fe-Mn oxide supported on graphene oxide and carbon Vulcan was also proposed, obtaining a very good catalytic activity of oxygen reduction to water in a microbial fuel cell with a power density of $450 \mathrm{mWm}^{-2}$ [129]. Huang and co-workers proposed a $\mathrm{CoFe}_{2} \mathrm{O}_{2}$ onto $\mathrm{N}$-doped graphene oxide as catalyst with a very large surface area and low resistance with a direct four-electron transfer during the oxygen reduction. MFC cathode modified with $\mathrm{CoFe}_{2} \mathrm{O}_{2}$ onto $\mathrm{N}$-doped graphene oxide produced a power of $1771 \mathrm{mWm}^{-2}$, demonstrating promising practical application in prototypes [130]. Bukitt and collaborators developed an FePc-MnOx on carbon Cabot composite catalyst and demonstrated the high oxygen reduction performance in neutral media. In an air-cathode MFC, the catalyst achieved $143 \mathrm{mWm}^{-2}$, higher than bare FePc on carbon Cabot as catalyst. This affect was attributed to the ability of bimetallic-TMO of decreasing hydrogen peroxide production, thus avoiding the poisoning of MnOx during ORR [131].

Figure 5 shows a schematic of a carbon supported MnOx-based catalyst and performance (in terms of peak power density) of different type of TMO catalysts in air-cathode MFC devices.
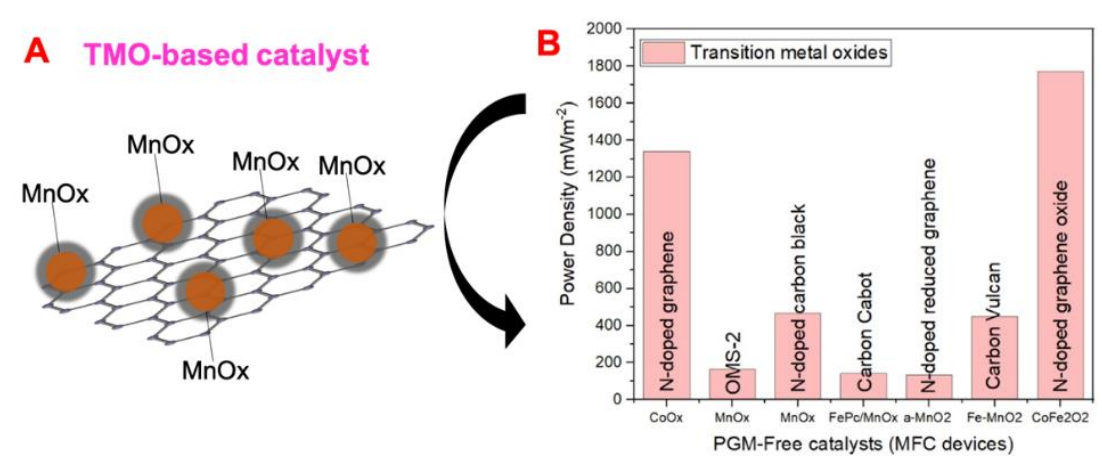

Figure 5. Schematics of a carbon supported MnOx-based catalyst (A) and performance (in terms of peak power density) of different type of TMO catalysts in air-cathode MFC devices (B). 


\subsection{Metal-Free Catalysts}

Metal-free carbon materials, such as biochar and activated carbon, have attracted the interest of the scientific community owing to their properties such as availability in large scale from secondary sources and a high surface area, which in turn enhances the ORR kinetics [132-134]. Activated carbon (AC) is a pyrogenic carbonaceous material produced by thermal or chemical activation of a wide range of carbonaceous precursors, such as carbon black, carbon black pearls, carbon nanotubes, and graphene. Biochar is produced from sustainable biomass sources, as a corncob, olive mill waste, pistachio salted, coconut shell, hardwood carbon, and bituminous coal [132,135-139]. However, it is not always possible to establish a rigorous distinction between activated carbon and biochar, and research on both materials is somehow overlapping [140].

As an added valued, the use of biochar in energy conversion and storage devices allows biomass valorization and takes into account the principles of green energy and sustainability. Dhelipan and co-workers have produced hierarchical carbon foams from orange peel as an active catalyst toward oxygen reduction in a fuel cell [141]. Yaokong et al. have fabricated a hierarchical high surface area $\left(1650 \mathrm{~m}^{2} \mathrm{~g}^{-1}\right)$ biochar from banana peel as catalyst in supercapacitors. The high surface area provides a favourable path for electrolyte penetration and transportation, which gives rise to excellent electrochemical properties for oxygen reduction to water [142].

Along with surface area, the surface chemistry of biochar is also of paramount importance in accelerating oxygen reduction. Different works have pointed that heteroatom doping improves the catalytic activity of the resulting biochar. Using nitrogen-containing chemicals during production and activation of either biochar or AC is one of the most effective methods for improving ORR catalysis; in fact, treatment with ammonia gas at a temperature higher than $600^{\circ} \mathrm{C}$ partially removes oxygen functional groups, but also introduces $\mathrm{N}$ atoms, leading to higher activity than that of untreated carbon $[136,137]$.

As far as MFC application is concerned, Li-Fang and collaborators have used inner membrane passion fruits to produce extremely porous biochar nanosheets. In neutral media, the catalyst exhibits remarkable electrocatalytic activity towards ORR. When assembled at the cathode side of an MFC, the catalysts allowed achieving a maximum power density of $1153 \mathrm{mWm}^{-2}$ achieved in the microbial fuel cells (MFCs), which is comparable to that of commercial Pt/C $\left(1214 \mathrm{mWm}^{-2}\right)$ [143]. Yuan et al. have studied the catalytic behavior of sewage sludge biochar at different pyrolysis temperatures. Treating at temperatures as high as $900^{\circ} \mathrm{C}$ allowed obtaining a material with super high micro porosity and a very high nitrogen content, which were crucial for achieving a high catalytic activity in MFCs with a power density of $500 \mathrm{mWm}^{-2}$, followed by good stability and good methanol tolerance [6]. A similar conclusion was drawn by Yuan et al., who prepared biochar from banana; the authors found that ORR is improved for the materials obtained with thermal treatments at $\mathrm{T}=900{ }^{\circ} \mathrm{C}$, and the highest power density achieved was $528 \mathrm{mWm}^{-2}$, which is comparable to that achieved with a control $\mathrm{Pt} / \mathrm{C}$ cathode [136]. Li and co-workers demonstrated the ORR catalytic efficiency of biochar derived from corncob, obtaining a maximum volumetric power density of $459 \mathrm{mWm}^{-3}$ in an MFC [144]. Chang et al. fabricated a biochar catalyst by pyrolyzing balsa wood chips at $800^{\circ} \mathrm{C}$. When assembled as air-cathode catalyst in a single-chamber MFC, a maximum power density of $200 \mathrm{mWm}^{-2}$ was achieved [145]. Liu et al. proposed an egg-derived heteroatom-doped mesoporous biochar. The one-step synthesis resulted in a low cost strategy to produce an efficient and active biochar catalyst in MFCs; maximum power density was $737 \mathrm{mWm}^{-2}$, higher than that achieved with control Pt/C $20 \%$ cathode $\left(704 \mathrm{mWm}^{-2}\right)$ [146]. Moreover, orange peel and olive mill wastes have been proven to be a suitable biomass source to obtain biochar with an interplay between surface chemistry and morphology, which enhances oxygen reduction at the cathode side of MFCs [147-149].

Even though it is generally accepted that metal-free catalysts promote hydrogen peroxide production through an ORR mechanism that involves two-electron transfer [133], Zhong et al. found that a high content of carbon-nitrogen bonds (including a high concentration of pyridinic nitrogen and graphitic nitrogen) in the prepared biochar facilitated a four-electron transfer pathway during 
oxygen reduction in an MFC [134]. On the other hand, chemical activation can introduce impurities into a carbon- and N-doped carbon-based metal-free catalyst; the biomass source can also bring metal residues in the obtained biochar. It has been demonstrated that even trace metals (such as $\mathrm{Fe}, \mathrm{Co}$, and Mn), below the detection limit of XPS and common TEM, X-ray diffraction (XRD), and energy dispersive X-ray spectrometry (EDS), play a dominant role in boosting activity of heteroatom-doped carbon materials for oxygen reduction reaction (ORR) [132,150-153]. Hence, the designation of AC catalysts fabricated using metal precursors as metal-free catalysts should be avoided, unless providing a proof of their complete removal or of their non-involvement in the electrocatalytic reaction of interest. Hence, it is recommended to reserve the designation of metal-free catalysts for materials prepared without any metallic precursors, possibly subjected to an ad hoc characterization including inductively coupled plasma optical emission spectrometry (ICP-OES), neutron activation analysis (NAA), magnetic susceptibility, and X-ray fluorescence analysis (XRF) [154].

Table 3 summarizes previous studies dealing with biochar catalyst as cathodic catalysts in microbial fuel cells for energy recovery.

Table 3. Summary of the MFC performance (power density) of biochar catalysts obtained by different sources of biomass, and different pyrolysis treatments.

\begin{tabular}{cccc}
\hline Biomass & Pyrolysis T & Power Density & Ref. \\
\hline Sewage sludge & $900{ }^{\circ} \mathrm{C}$ & $500 \mathrm{mWm}^{-2}$ & {$[6]$} \\
Banana & $900{ }^{\circ} \mathrm{C}$ & $528 \mathrm{mWm}^{-2}$ & {$[136]$} \\
Passion fruit & $900{ }^{\circ} \mathrm{C}$ & $1153 \mathrm{mWm}^{-2}$ & {$[143]$} \\
Corncob & $650{ }^{\circ} \mathrm{C}$ & $459 \mathrm{mWm}^{-2}$ & {$[144]$} \\
Balsa wood & $800^{\circ} \mathrm{C}$ & $200 \mathrm{mWm}^{-2}$ & {$[145]$} \\
Egg & $900{ }^{\circ} \mathrm{C}$ & $737 \mathrm{mWm}^{-2}$ & {$[146]$} \\
Orange peel & $50{ }^{\circ} \mathrm{C}$ & $359 \mathrm{mWm}^{-2}$ & {$[147]$} \\
Pt/C & - & $704 \mathrm{mWm}^{-2}$ & {$[146]$} \\
\hline
\end{tabular}

As highlighted by the table, a pyrolysis step at temperatures as high as $900{ }^{\circ} \mathrm{C}$ is necessary to achieve a high power density output in an MFC.

\section{Conclusions and Outlook}

In the past years, microbial fuel cell (MFC) devices have attracted researchers' attention owing to their capability of harvesting energy from waste treatment. Different studies have pointed to the development of alternative catalysts to replace platinum and platinum group metals (PGMs) at the cathode side of MFCs. Herein, this review provides an overview of different catalysts based on PGM-free catalysts for microbial fuel cell devices. The most common approaches for replacing platinum as oxygen reduction catalyst result in three different families of materials: (i) enzyme catalysts, (ii) transition metal-nitrogen-carbon (M-N-C) catalysts, and (iii) metal-free catalysts.

Enzymes have high biocompatibility, high efficiency, and activity under mild conditions; these advantages are suitable for their use in the next-generation green power source system. In addition, enzyme high specificity toward substrates allows a simple fuel cell design without using a separator between the anode and cathode, which is usually necessary to avoid cross diffusion of oxidant and fuel in traditional fuel cells. On the other hand, there are some obstacles to overcome for practical applications. One of the major problems is limited long-term stability of enzyme-based fuel cells, which is caused by denaturation or conformational change of enzymes. The immobilized enzymes on an electrode can be active for a few weeks, but this is still short as a part of real application devices. Significant progress on the lifetime extension has been made by encapsulation of the enzyme in the micelles or polymer layer, which physically confines the enzymes preventing denaturation, or utilizing the enzymes from thermophilic microorganisms.

$\mathrm{M}-\mathrm{N}-\mathrm{C}$ catalysts have been developed using different sources of transition metals such as iron, cobalt, manganese, and nickel, owing to their redox couples $\left(\mathrm{Fe}^{2+/ 3+}, \mathrm{Co}^{2+/ 3+}, \mathrm{Mn}^{3+/ 4}+\right.$, and $\left.\mathrm{Ni}^{3+/ 4+}\right)$, 
nitrogen and carbon. Those materials are less expensive and have lower sensitivity to poisoning in comparison with PGM materials. Different conductive carbon material (carbon black, carbon nanotubes, graphene, graphene oxide, carbon nanofibers) are used as carbon sources, mainly providing a high high electrical conductivity, and a suitable surface area and porosity to guarantee a high density of active sites for ORR. Usually, the properties of carbon materials facilitate the modification and optimization of their structure, morphology, and surface chemistry. Heteroaton (nitrogen, phosphorous, sulphur, oxygen) doping enhances metal coordination with the carbon matrix, while maintaining the accessibility of active sites.

Among these, iron-based materials have demonstrated promising ORR activity and stability as compared with the catalysts based on different transition metals. In the case of Fe-N-C catalysts, morphology and structure was found to be strongly dependent on the pyrolysis temperature. The temperature affects the porosity, stabilisation, and solubilisation of the composite, increasing the coordination of Fe- $\mathrm{N}$ with carbon substrate via $\pi-\pi$ interaction. A significant effort is still needed to obtain a full understanding of active site structure of pyrolyzed Fe-N-C catalyst and its relationship with activity and stability in MFC operating conditions. F-N-C catalysts can also be obtained using a pyrolysis-free approach. In these molecular catalysts, $\mathrm{Fe}-\mathrm{N}_{4}$ structures supported on different nanostructured carbon substrates have shown significant performance toward oxygen reduction to water in MFC. Iron phthalocyanine ( $\mathrm{FePc}$ ) macrocycles have demonstrated high catalytic activity and tolerance to poisoning in neutral media in comparison with $\mathrm{Pt} / \mathrm{C}$-based catalysts. On the other hand, a significant effort is still needed to increase the stability of molecular catalysts. The development of transition metal oxide (TMO) catalysts has also enhanced the oxygen performance competitiveness with $\mathrm{Pt} / \mathrm{C}$ electrocatalysts in air-cathode MFCs. Still, further efforts are required to gain a better understanding of the ORR mechanism, and how a second metal (such as binary-metal oxide) allows preventing hydrogen peroxide formation. Many other studies have demonstrated the high activity of metal-free such as ORR catalysts in microbial fuel cells. Different biomass sources (such as banana peel, orange peel, corncob, balsa wood) can be used to obtain biochar with $\mathrm{N}$ and $\mathrm{O}$ surface functional groups, providing a high power density even comparable to that obtained with $\mathrm{Pt} / \mathrm{C}$-based catalysts. Meanwhile, to further promote the applicability of biochar in MFCs, a deeper understanding of the real composition of these catalysts and the role of the surface functionalities on ORR is still needed.

To conclude, this review discusses current challenges and perspectives of the most exploited types of PGM-free catalysts for application in bioelectrochemical systems. We have shown the best performing catalysts toward oxygen reduction in microbial fuel cells and have also highlighted the challenges to be overcome, especially on improving the activity, active sites, and stability, and ORR mechanisms in neutral media. In this context, the state-of-the-art of platinum group metal-free (PGM-free) and metal-free catalysts are good candidates to replace precious catalysts at the cathode side of microbial fuel cells.

Author Contributions: Conceptualization and planning the manuscript structure, M.A.C.d.O. and B.M.; writing-original draft preparation, M.A.C.d.O.; contribution to writing some part of this review, H.O.; resources and funding acquisition, M.A.C.d.O, B.M., and A.D.; writing-review and editing, B.M.; project administration, B.M.; supervision, B.M. and A.D. All authors have read and agreed to the published version of the manuscript.

Funding: This research was funded by the University of Roma Tor Vergata (Grant "BEYOND BORDERS 2019": Project Name: AEROBIC) and CNPq-Conselho Nacional de Desenvolvimento Científico e Tecnologico, Brazil, under the grant n. 200631-2015/2.

Conflicts of Interest: The authors declare no conflict of interest. 


\section{References}

1. Jung, S.; Lee, J.; Park, Y.K.; Kwon, E.E. Bioelectrochemical systems for a circular bioeconomy. Bioresour. Technol. 2020, 300, 122748. [CrossRef]

2. Ivase, T.J.P.; Nyakuma, B.B.; Oladokun, O.; Abu, P.T.; Hassan, M.N. Review of the principal mechanisms, prospects, and challenges of bioelectrochemical systems. Environ. Prog. Sustain. Energy 2020, 39, e13298. [CrossRef]

3. Zhang, X.; Li, X.; Zhao, X.; Li, Y. Factors affecting the efficiency of a bioelectrochemical system: A review. RSC Adv. 2019, 9, 19748-19761. [CrossRef]

4. Rinaldi, A.; Mecheri, B.; Garavaglia, V.; Licoccia, S.; Di Nardo, P.; Traversa, E. Engineering materials and biology to boost performance of microbial fuel cells: A critical review. Energy Environ. Sci. 2008, 1, 417-429. [CrossRef]

5. Katz, E. Biofuel Cells with Switchable Power Output. Electroanalysis 2010, 22, 744-756. [CrossRef]

6. Yuan, Y.; Yuan, T.; Wang, D.; Tang, J.; Zhou, S. Sewage sludge biochar as an efficient catalyst for oxygen reduction reaction in a microbial fuel cell. Biosour. Technol. 2013, 144, 115-120. [CrossRef]

7. Vries, S.C.; van de Ven, G.W.J.; van Ittersum, M.K.; Giller, K.E. Resource use efficiency and environmental performance of nine major biofuel crops, processed by first-generation conversion techniques. Biomass Bioenergy 2010, 34, 588-601. [CrossRef]

8. Cecconet, D.; Callegari, A.; Capodaglio, A.G. Bioelectrochemical systems for removal of selected metals and perchlorate from groundwater: A review. Energies 2018, 11, 2643. [CrossRef]

9. Fang, C.; Achal, V. The potential of microbial fuel cells for remediation of heavy metals from soil and water-Review of application. Microorganisms 2019, 7, 697. [CrossRef]

10. Włodarczyk, P.P.; Włodarczyk, B. Microbial fuel cell with Ni-Co cathode powered with yeast wastewater. Energies 2018, 11, 3194. [CrossRef]

11. Sanchez, D.V.P.; Jacobs, D.; Gregory, K.; Huang, J.; Hu, Y.; Vidic, R.; Yun, M. Changes in carbon electrode morphology affect microbial fuel cell performance with Shewanella oneidensis MR-1. Energies 2015, 8, 1817-1829. [CrossRef]

12. Włodarczyk, P.P.; Włodarczyk, B. Preparation and analysis of ni-co catalyst use for electricity production and COD reduction in microbial fuel cells. Catalysts 2019, 9, 1042. [CrossRef]

13. Kabutey, F.T.; Zhao, Q.; Wei, L.; Ding, J.; Antwi, P.; Quashie, F.K.; Wang, W. An overview of plant microbial fuel cells (PMFCs): Configurations and applications. Renew. Sustain. Energy Rev. 2019, 110, $402-414$. [CrossRef]

14. Christwardana, M.; Frattini, D.; Accardo, G.; Yoon, S.P.; Kwon, Y. Effects of methylene blue and methyl red mediators on performance of yeast based microbial fuel cells adopting polyethylenimine coated carbon felt as anode. J. Power Sources 2018, 396, 1-11. [CrossRef]

15. Jannelli, N.; Anna Nastro, R.; Cigolotti, V.; Minutillo, M.; Falcucci, G. Low pH, high salinity: Too much for microbial fuel cells? Appl. Energy 2017, 192, 543-550. [CrossRef]

16. Addi, H.; Mateo-Ramírez, F.; Ortiz-Martínez, V.M.; Salar-García, M.J.; Hernández-Fernández, F.J.; de los Ríos, A.P.; Godínez, C.; Lotfi, E.M.; Mahi, M.E.; Blanco, L.J.L. Treatment of mineral oil refinery wastewater in microbial fuel cells using ionic liquid based separators. Appl. Sci. 2018, 8, 438. [CrossRef]

17. Santoro, C.; Arbizzani, C.; Erable, B.; Ieropoulos, I. Microbial fuel cells: From fundamentals to applications. A review. J. Power Sources 2017, 356, 225-244. [CrossRef]

18. Do, M.H.; Ngo, H.H.; Guo, W.S.; Liu, Y.; Chang, S.W.; Nguyen, D.D.; Nghiem, L.D.; Ni, B.J. Challenges in the application of microbial fuel cells to wastewater treatment and energy production: A mini review. Sci. Total Environ. 2018, 639, 910-920. [CrossRef]

19. Santoro, S.; Kodali, M.; Herrera, S.; Serov, A.; Ieropoulos, I.; Atanassov, P. Power generation in microbial fuel cells using platinum group metal-free cathode catalyst: Effect of the catalyst loading on performance and costs. J. Power Sources 2018, 378, 169-175. [CrossRef]

20. Oliveira, M.A.C.; Mecheri, B.; D’Epifanio, A.; Placidi, E.; Arciprete, F.; Valentini, F.; Perandini, A.; Valentini, V.; Licoccia, S. Graphene oxide nanoplatforms to enhance catalytic performance of iron phthalocyanine for oxygen reduction reaction in bioelectrochemical systems. J. Power Sources 2017, 356, 381-388. [CrossRef] 
21. Santoro, C.; Serov, A.; Stariha, L.; Kodali, M.; Gordon, J.; Babanova, S.; Bretschger, O.; Artyushkova, K.; Atanassov, P. Iron based catalysts from novel low-cost organic precursors for enhanced oxygen reduction reaction in neutral media microbial fuel cells. Energy Environ. Sci. 2016, 9, 2346-2353. [CrossRef]

22. Rojas-Carbonell, S.; Santoro, C.; Serov, A.; Atanassov, P. Transition metal-nitrogen-carbon catalysts for oxygen reduction reaction in neutral electrolyte. Electrochem. Commun. 2017, 75, 38-42. [CrossRef]

23. Bajracharya, S.; Sharma, M.; Mohanakrishna, G.; Benneton, X.D.; Strik, D.P.B.T.B.; Sarma, P.M.; Pant, D. An overview on emerging bioelectrochemical systems (BESs): Technology for sustainable electricity, waste remediation, resource recovery, chemical production and beyond. Renew. Energy 2016, 98, 153-170. [CrossRef]

24. Xiao, X.; Xia, H.Q.; Wu, R.; Bai, L.; Yan, L.; Magner, E.; Cosnier, S.; Lojou, E.; Zhu, Z.; Liu, A. Tackling the challenges of enzymatic (bio) fuel cells. Chem. Rev. 2019, 119, 9509-9958. [CrossRef] [PubMed]

25. Osman, M.H.; Shah, A.A.; Walsh, F.C. Biosensors and Bioelectronics Recent progress and continuing challenges in bio-fuel cells. Part I: Enzymatic cells. Biosens. Bioelectron. 2011, 26, 3087-3102. [CrossRef] [PubMed]

26. Willner, I.; Katz, E. Integration of layered redox proteins and conductive supports for bioelectronic applications. Angew. Chem. Int. Ed. 2000, 39, 1180-1218. [CrossRef]

27. Mecheri, B.; De Porcellinis, D.; Campana, P.T.; Rainer, A.; Trombetta, M.; Marletta, A.; Oliveira, N.O., Jr.; Licoccia, S. Tuning structural changes in glucose oxidase for enzyme fuel cell applications. ACS Appl. Mater. Interfaces 2015, 7, 28311-28318. [CrossRef]

28. Mano, N.; De Poulpiquet, A. $\mathrm{O}_{2}$ reduction in enzymatic biofuel cells. Chem. Rev. 2018, 118, $2392-2468$. [CrossRef]

29. Shleev, S.; Tkac, J.; Christenson, A.; Ruzgas, T.; Yaropolov, A.I.; Whittaker, J.W.; Gorton, L. Direct electron transfer between copper-containing proteins and electrodes. Biosens. Bioelectron. 2005, 20, 2517-2554. [CrossRef]

30. Kamitaka, Y.; Tsujimura, S.; Kataoka, S.; Sakurai, T.; Ikeda, T.; Kano, K. Effects of axial ligand mutation of the type I copper site in bilirubin oxidase on direct electron transfer-type bioelectrocatalytic reduction of dioxygen. J. Electroanal. Chem. 2007, 601, 119-124. [CrossRef]

31. Miura, Y.; Tsujimura, S.; Kurose, S.; Kamitaka, Y.; Kataoka, K.; Sakurai, T.; Kano, K. Direct electrochemistry of CueO and its mutants at residues to and near type I Cu for oxygen-reducing biocathode. Fuel Cells 2009, 9, 70-78. [CrossRef]

32. Gooding, J.J.; Wibowo, R.; Liu, J.; Yang, W.; Losic, D.; Orbons, S.; Mearns, F.J.; Shapter, J.G.; Hibbert, D.B. Protein electrochemistry using aligned carbon nanotube arrays. J. Am. Chem. Soc. 2003, 125, 9006-9007. [CrossRef] [PubMed]

33. Zheng, W.; Li, Q.; Su, L.; Yan, Y.; Zhang, J.; Mao, L. Direct electrochemistry of multi-copper oxidases at carbon nanotubes noncovalently functionalized with cellulose derivatives. Electroanalysis 2006, 18, 587-594. [CrossRef]

34. Cass, A.E.G.; Davis, G.; Francis, G.D.; Hill, H.A.O.; Aston, W.J.; Higgins, I.J.; Plotkin, E.V.; Scott, L.D.L.; Turner, A.P.F. Ferrocene-mediated enzyme electrode for amperometric determination of glucose. Anal. Chem. 1984, 56, 667-671. [CrossRef]

35. Tsujimura, S.; Tatsumi, H.; Ogawa, J.; Shimizu, S.; Kano, K.; Ikeda, T. Bioelectrocatalytic reduction of dioxygen to water at neutral $\mathrm{pH}$ using bilirubin oxidase as an enzyme and 2,2-azinobis (3-ethylbenzothiazolin-6-sulfonate) as an electron transfer mediator. J. Electroanal. Chem. 2001, 496, 69-75. [CrossRef]

36. Patolsky, F.; Lichtenstein, A.; Willner, I. Electronic transduction of DNA sensing processes on surfaces: Amplification of DNA detection and analysis of single-base mismatches by tagged liposomes. J. Am. Chem. Soc. 2001, 123, 5194-5205. [CrossRef] [PubMed]

37. Ohnuki, H.; Wako, T.; Mecheri, B.; Wu, H.; Tsuya, D.; Endo, H. Self-powered hydrogen peroxide sensor and its application as a biosensor. Jpn. J. Appl. Phys. 2019, 58, SBBG16. [CrossRef]

38. Ohnuki, H.; Saiki, T.; Kusakari, A.; Endo, H.; Ichihara, M.; Izumi, M. Incorporation of glucose oxidase into langmuir-blodgett films based on prussian blue applied to amperometric glucose biosensor. Langmuir 2007, 23, 4675-4681. [CrossRef]

39. Mano, N.; Mao, F.; Heller, A. On the parameters affecting the characteristics of the 'wired' glucose oxidase anode. J. Electroanal. Chem. 2005, 574, 347-357. [CrossRef] 
40. Heller, A. Electron-conducting redox hydrogels: Design, characteristics and synthesis. Curr. Opin. Chem. Biol. 2006, 10, 664-672. [CrossRef]

41. Wang, H.; Ohnuki, H.; Endo, H.; Izumi, M. Impedimetric and amperometric bifunctional glucose biosensor based on hybrid organic-inorganic thin films. Bioelectrochemistry 2005, 101, 1-7. [CrossRef] [PubMed]

42. Moore, C.M.; Akers, N.L.; Hill, A.D.; Johnson, Z.C.; Minteer, S.D. Improving the environment for immobilized dehydrogenase enzymes by modifying nafion with tetraalkylammonium bromides. Biomacromolecules 2004, 5, 1241-1247. [CrossRef] [PubMed]

43. Beneyton, T.; El Harrak, A.; Griffiths, A.D.; Hellwig, P.; Taly, V. Immobilization of CotA, an extremophilic laccase from Bacillus subtilis, on glassy carbon electrodes for biofuel cell applications. Electrochem. Commun. 2011, 13, 24-27. [CrossRef]

44. Nimje, V.R.; Chen, C.C.; Chen, H.R.; Chen, C.Y.; Tseng, M.J.; Cheng, K.C.; Shih, R.C.; Chang, Y.F. A single-chamber microbial fuel cell without an air cathode. Int. J. Mol. Sci. 2012, 13, 3933-3948. [CrossRef]

45. Cheng, S.; Liu, H.; Logan, B.E. Increased performance of single-chamber microbial fuel cells using an improved cathode structure. Electrochem. Commun. 2006, 8, 489-494. [CrossRef]

46. Logan, B.E.; Cheng, S.; Watson, V.; Estadt, G. Graphite fiber brush anodes for increased power production in air-cathode microbial fuel cells. Environ. Sci. Technol. 2007, 9, 3341-3346. [CrossRef]

47. Rozendal, R.A.; Hamelers, H.V.M.; Rabaey, K.; Keller, J.; Buisman, C.J.N. Towards practical implementation of bioelectrochemical wastewater treatment. Trends Biotechnol. 2008, 26, 450-459. [CrossRef]

48. Rismani-Yazdi, S.M.H.; Carver, A.D.; Christy, O.H. Cathodic limitations in microbial fuel cells: An overview. J. Power Sources 2008, 180, 683-694. [CrossRef]

49. Wang, Z.; Mahadevan, G.D.; Wu, Y.; Zhao, F. Progress of air-breathing cathode in microbial fuel cells. J. Power Sources 2017, 356, 245-255. [CrossRef]

50. Li, Y.; Li, Q.; Wang, H.; Zhang, L.; Wilkinson, D.P.; Zhang, J. Recent progresses in oxygen reduction reaction electrocatalysts for electrochemical energy applications. Electrochem. Energy Rev. 2019, 2, 518-538. [CrossRef]

51. Choi, C.H.; Kwon, H.C.; Yook, S.; Shin, H.; Kim, H.; Choi, M. Hydrogen peroxide synthesis via enhanced two-electron oxygen reduction pathway on carbon-coated Pt surface. J. Phys. Chem. C 2014, 118, 30063-30070. [CrossRef]

52. Ma, R.; Lin, G.; Zhou, Y.; Liu, Q.; Zhang, T.; Shan, G.; Yang, M.; Wang, J. A review of oxygen reduction mechanisms for metal-free carbon-based electrocatalysts. npj Comput. Mater. 2019, 5, 1-15. [CrossRef]

53. Zhou, R.; Zheng, Y.; Jaroniec, M.; Qiao, S.-Z. Determination of the electron transfer number for the oxygen reduction reaction: From theory to experiment. ACS Catal. 2016, 6, 4720-4728. [CrossRef]

54. Yang, T.; Wang, M.; Ju, X.; Zhao, J.; Fu, C. The efficient oxygen reduction catalysts based on the non-noble metal and conducting polymers. Int. J. Electrochem. Sci. 2017, 12, 12125-12139. [CrossRef]

55. Ramaswamy, N.; Mukerjee, S. Fundamental mechanistic understanding of electrocatalysis of oxygen reduction on Pt and non-Pt surfaces: Acid versus Alkaline Media. Adv. Phys. Chem. 2012, 491604, 1-17. [CrossRef]

56. Wu, S.-H.; Li, P.-C. Electron transfer number control of the oxygen reduction reaction on nitrogen-doped reduced graphene oxides for the air electrodes of zinc-air batteries and organic degradation. Mater. Chem. Phys. 2016, 183, 551-560. [CrossRef]

57. Brocato, S.; Serov, A.; Atanassov, P. PH dependence of catalytic activity for ORR of the non-PGM catalyst derived from heat-treated Fe-phenanthroline. Electrochim. Acta 2013, 87, 361-365. [CrossRef]

58. Xie, J.; Li, S.; Zhang, X.; Zhang, J.; Wang, R.; Zhang, H.; Pan, B.; Xie, Y. Atomically thin molybdenum nitride nanosheets with exposed active surface sites for efficient hydrogen evolution. Chem. Sci. 2014, 5, 4615-4620. [CrossRef]

59. Chen, W.; Fan, Z.; Gu, L.; Bao, X.; Wang, C. Enhanced capacitance of manganese oxide via confinement inside carbon nanotubes. Chem. Commun. 2010, 46, 3905-3907. [CrossRef]

60. Madkikar, P.; Menga, D.; Harzer, G.S.; Mittermeier, T.; Siebel, A.; Wagner, F.E.; Merz, M.; Schuppler, S.; Nagel, P.; Muñoz-García, A.B.; et al. Nanometric Fe-substituted $\mathrm{ZrO}_{2}$ on carbon black as PGM-free ORR catalyst for PEMFCs. J. Electrochem. Soc. 2019, 166, F3032-F3043. [CrossRef]

61. Mecheri, B.; Ficca, V.C.A.; Oliveira, M.A.C.; Placidi, E.; Arciprete, F.; D’Epifanio, A.; Licoccia, S. Facile synthesis of graphene-phthalocyanine composites as oxygen reduction electrocatalysts in microbial fuel cells. Appl. Catal. B-Environ. 2018, 237, 699-707. [CrossRef] 
62. Oliveira, M.A.C.; Mecheri, B.; Zurlo, F.; D’Epifanio, A.; Licoccia, S. Optimization of PGM-free cathodes for oxygen reduction in microbial fuel cells. Electrochim. Acta 2020, 334, 135650. [CrossRef]

63. Jiang, K.; Back, S.; Akey, A.J.; Xia, C.; Hu, Y.; Liang, W.; Schaak, D.; Stavitski, E.; Nørskov, J.K.; Siahrostami, S.; et al. Highly selective oxygen reduction to hydrogen peroxide on transition metal single atom coordination. Nat. Commun. 2019, 10,1-11. [CrossRef] [PubMed]

64. Liu, M.; Wang, L.; Zhao, K.; Shi, S.; Shao, S.; Zhang, L.; Sun, X.; Zhao, Y.; Zhang, J. Atomically dispersed metal catalysts for the oxygen reduction reaction: Synthesis, characterization, reaction mechanisms and electrochemical energy applications. Energy Environ. Sci. 2019, 12, 2890-2923. [CrossRef]

65. Setzler, B.P.; Zhuang, Z.; Wittkop, J.A.; Yan, Y. Activity targets for nanostructured platinum-group-metal-free catalysts in hydroxide exchange membrane fuel cells. Nat. Nanotechnol. 2016, 11, 1020-1025. [CrossRef]

66. Lefèvre, M.; Proietti, E.; Jaouen, F.; Dodelet, J.P. Iron-based catalysts with improved oxygen reduction activity in polymer electrolyte fuel cells. Science 2009, 324, 71-74. [CrossRef]

67. Jaouen, F.; Proietti, E.; Lefèvre, M.; Chenitz, R.; Dodelet, J.P.; Wu, G.; Chung, H.T.; Johnston, C.M.; Zelenay, P. Recent advances in non-precious metal catalysis for oxygen-reduction reaction in polymer electrolyte fuel cells. Energy Environ. Sci. 2011, 4, 114-130. [CrossRef]

68. Artyushkova, K.; Serov, A.; Rojas-Carbonell, S.; Atanassov, P. Chemistry of multitudinous active sites for oxygen reduction reaction in transition metal-nitrogen-carbon electrocatalysts. J. Phys. Chem. C 2015, 119, 25917-25928. [CrossRef]

69. Mohamed, H.O.; Sayed, E.T.; Obaid, M.; Choi, Y.J.; Park, S.G.; Al-Qaradawi, S.; Chae, K.J. Transition metal nanoparticles doped carbon paper as a cost-effective anode in a microbial fuel cell powered by pure and mixed biocatalyst cultures. Int. J. Hydrog. Energy 2018, 43, 21560-21571. [CrossRef]

70. Azargohar, R.; Dalai, A.K. Biochar is a precursor of activated carbon. Appl. Biochem. Biotech. 2006, 131, 762-773. [CrossRef]

71. Mineva, T.; Matanovic, I.; Atanassov, P.; Sougrati, M.-T.; Stievano, L.; Clémancey, M.; Kochem, A.; Latour, J.-M.; Jaouen, F. Understanding active sites in pyrolyzed Fe-N-C catalysts for fuel cell cathodes by bridging density functional theory calculations and 57Fe mössbauer spectroscopy. ACS Catal. 2019, 9, 9359-9371. [CrossRef]

72. Xu, X.; Xia, Z.; Zhang, X.; Sun, R.; Sun, X.; Li, H.; Wu, C.; Wang, J.; Wang, S.; Sun, G. Atomically dispersed Fe-N-C derived from dual metal-organic frameworks as efficient oxygen reduction electrocatalysts in direct methanol fuel cells. Appl. Catal. B Environ. 2019, 259, 118042. [CrossRef]

73. Yin, X.; Utetiwabo, W.; Sun, S.; Lian, Y.; Chen, R.; Yang, W. Incorporation of CeF3 on single-atom dispersed $\mathrm{Fe} / \mathrm{N} / \mathrm{C}$ with oxophilic interface as highly durable electrocatalyst for proton exchange membrane fuel cell. J. Catal. 2019, 374, 43-50. [CrossRef]

74. Ratso, S.; Sougrati, M.T.; Käärik, M.; Merisalu, M.; Rähn, M.; Kisand, V.; Kikas, A.; Paiste, P.; Leis, J.; Sammelselg, V.; et al. Effect of ball-milling on the oxygen reduction reaction activity of iron and nitrogen co-doped carbide-derived carbon catalysts in acid media. ACS Appl. Energy Mater. 2019, 2, 7952-7962. [CrossRef]

75. Nabae, Y.; Moriya, S.; Matsubayashi, K.; Lyth, S.M.; Malon, M.; Wu, L.; Islam, N.M.; Koshigoe, Y.; Kuroki, S.; Kakimoto, M.A.; et al. The role of Fe species in the pyrolysis of Fe phthalocyanine and phenolic resin for preparation of carbon-based cathode catalysts. Carbon 2010, 48, 2613-2624. [CrossRef]

76. Miller, H.A.; Bellini, M.; Oberhauser, W.; Deng, X.; Chen, H.; He, Q.; Passaponti, M.; Innocenti, M.; Yang, Y.; Sun, F.; et al. Heat treated carbon supported iron (II) phthalocyanine oxygen reduction catalysts: Elucidation of the structure-activity relationship using X-ray absorption spectroscopy. Phys. Chem. Chem. Phys. 2016, 18, 33142-33151. [CrossRef] [PubMed]

77. Zhang, H.; Chung, H.T.; Cullen, D.A.; Wagner, S.; Kramm, U.I.; More, K.L.; Zelenay, P.; Wu, G. High-performance fuel cell cathodes exclusively containing atomically dispersed iron active sites. Energy Environ. Sci. 2019, 12, 2548-2558. [CrossRef]

78. Zhang, Z.; Sun, J.; Wang, F.; Dai, L. Efficient oxygen reduction reaction (ORR) catalysts based on single iron atoms dispersed on a hierarchically structured porous carbon framework. Angew. Chem. Int. Ed. 2018, 57, $1-7$.

79. Ao, X.; Zhang, W.; Li, Z.; Lv, L.; Ruan, Y.; Wu, H.-H.; Chiang, W.-H.; Wang, C.; Liue, M.; Zeng, X.C. Unraveling the high-activity nature of Fe-N-C electrocatalysts for oxygen reduction reaction: The extraordinary synergy between Fe-N4 and Fe4N. J. Mater. Chem. A 2012, 7, 11792-11801. [CrossRef] 
80. Chung, D.Y.; Kim, M.J.; Kang, N.; Yoo, J.M.; Shin, H.; Kim, O.-H.; Sung, Y.-E. Low-temperature and gram-scale synthesis of two-dimensional Fe-N-C carbon sheets for robust electrochemical oxygen reduction reaction. Chem. Mater. 2017, 29, 2890-2898. [CrossRef]

81. Chen, M.; He, Y.; Spendelow, J.S.; Wu, G. Atomically dispersed metal catalysts for oxygen reduction. ACS Energy Lett. 2019, 4, 1619-1633. [CrossRef]

82. Huang, X.; Yang, Z.; Dong, B.; Wang, Y.; Tang, T.; Hou, Y. In-situ Fe2N@N-doped porous carbon hybrids as superior catalysts for oxygen reduction reaction. Nanoscale 2013, 9, 8102-8106. [CrossRef] [PubMed]

83. Monteverde Videla, A.H.A.; Osmieri, L.; Specchia, S. Non-noble metal (NNM) catalysts for fuel cells: Tuning the activity by a rational step by step single variable evolution. In Electrochemistry of N4 Macrocyclic Metal Complexes; Bedioui, F., Zagal, J.H., Eds.; Springer International Publishing AG: Basel, Switzerland, 2016; pp. 69-101.

84. Monteverde Videla, A.H.A.; Osmieri, L.; Armandi, M.; Specchia, S. Varying the morphology of Fe-N-C electrocatalysts by templating Iron Phthalocyanine precursor with different porous $\mathrm{SiO}_{2}$ to promote the Oxygen Reduction Reaction. Electrochim. Acta 2014, 177, 43-50. [CrossRef]

85. Zagal, J.H.; Fethi, B. (Eds.) Electrochemistry of N4 Macrocyclic Metal Complexes; Springer: Berlin/Heidelberg, Germany, 2016; Volume 1: Energy.

86. Zhang, Z.; Dou, M.; Ji, J.; Wang, F. Phthalocyanine tethered iron phthalocyanine on graphitized carbon black as superior electrocatalyst for oxygen reduction reaction. Nano Energy 2017, 34, 338-343. [CrossRef]

87. Cui, L.; Lv, G.; Dou, Z.; He, X. Fabrication of iron phthalocyanine/graphene micro/nanocomposite by solvothermally assisted $\pi-\pi$ assembling method and its application for oxygen reduction reaction. Electrochim. Acta 2013, 106, 272-278. [CrossRef]

88. Taniguchi, T.; Tateishi, H.; Miyamoto, S.; Hatakeyama, K.; Ogata, C.; Funatsu, A.; Hayami, A.; Makinose, Y.; Matsushita, N.; Koinuma, M.; et al. A self-assembly route to an iron phthalocyanine/reduced graphene oxide hybrid electrocatalyst affording an ultrafast oxygen reduction reaction. Part. Part. Syst. Charact. 2013, 30, 1063-1070. [CrossRef]

89. Jiang, Y.; Lu, Y.; Lv, X.; Han, D.; Zhang, Q.; Niu, L.; Chen, W. Enhanced catalytic performance of Pt free iron phthalocyanine by graphene support for efficient oxygen reduction reaction. ACS Catal. 2013, 3, 1263-1271. [CrossRef]

90. Zhang, C.; Hao, Z.; Yin, H.; Liu, H.; Hou, L. Iron phthalocyanine and nitrogen-doped graphene composite as a novel non-precious catalyst for the oxygen reduction reaction. Nanoscale 2013, 4, 7326-7329. [CrossRef]

91. Oliveira, M.A.C.; Ficca, V.C.A.; Gokhale, R.; Santoro, C.; Mecheri, B.; D’Epifanio, A.; Licoccia, S.; Atanassov, P. Iron(II) phthalocyanine (FePc) over carbon support for oxygen reduction reaction electrocatalysts operating in alkaline electrolyte. J. Solid State Electrochem. 2020, 1-12. [CrossRef]

92. Osmieri, L.; Monteverde Videla, A.H.A.; Armandi, M.; Specchia, S. Influence of different transition metals on the properties of Me-N-C (Me $=\mathrm{Fe}, \mathrm{Co}, \mathrm{Cu}, \mathrm{Zn})$ catalysts synthesized using SBA-15 as tubular nano-silica reactor for oxygen reduction reaction. Int. J. Hydrog. Energy 2016, 41, 22570-22588. [CrossRef]

93. Santoro, C.; Rojas-Carbonell, S.; Awais, R.; Gokhale, R.; Kodali, M.; Serov, A.; Artyushkova, K.; Atanassov, P. Influence of platinum group metal-free catalyst synthesis on microbial fuel cell performance. J. Power Sources 2018, 375, 11-20. [CrossRef]

94. Chen, Y.; Artyushkova, K.; Rojas-Carbonell, S.; Serov, A.; Matanovic, I.; Santoro, C.; Atanassov, P. Inhibition of surface chemical moieties by tris(hydroxymethyl)aminomethane: A key to understanding oxygen reduction on iron-nitrogen-carbon catalysts. ACS Appl. Energy Mater. 2018, 1, 1942-1949. [CrossRef]

95. Mecheri, B.; Gokhale, R.; Santoro, C.; Oliveira, M.A.C.; D’Epifanio, A.; Licoccia, S.; Serov, A.; Artyushkova, K.; Atanassov, P. Oxygen reduction reaction electrocatalysts derived from iron salt and benzimidazole and aminobenzimidazole precursors and their application in microbial fuel cell cathode. ACS Appl. Energy Mater. 2018, 1, 5755-5765. [CrossRef] [PubMed]

96. Birry, L.; Mehta, P.; Jaouen, F.; Dodelet, J.-P.; Guiot, S.R.; Tartakovsky, B. Application of iron-based cathode catalysts in a microbial fuel cell. Electrochim. Acta 2011, 56, 1505-1511. [CrossRef]

97. Kodali, M.; Santoro, C.; Serov, A.; Kabir, S.; Artyushkova, K.; Matanovic, I.; Atanassov, P. Air breathing cathodes for microbial fuel cell using $\mathrm{Mn}-, \mathrm{Fe}-, \mathrm{Co}-$ and Ni-containing platinum group metal-free catalysts. Electrochim. Acta 2017, 231, 115-124. [CrossRef] [PubMed] 
98. Guo, X.; Wang, Q.; Xu, T.; Wei, K.; Yin, M.; Liang, P.; Huang, X.; Zhang, X. One-step ball milling-prepared nano $\mathrm{Fe}_{2} \mathrm{O}_{3}$ and nitrogen-doped graphene with high oxygen reduction activity and its application in microbial fuel cells. Front. Environ. Sci. Eng. 2020, 14, 30. [CrossRef]

99. Yang, W.; Wang, X.; Rossi, R.; Logan, B.E. Low-cost Fe-N-C catalyst derived from Fe (III)-chitosan hydrogel to enhance power production in microbial fuel cells. Chem. Eng. J. 2019, 380, 122522. [CrossRef]

100. Mahalingam, S.; Ayyaru, S.; Ahn, Y.-H. Enhanced cathode performance of $\mathrm{Fe}_{2} \mathrm{O}_{3}$, boron nitride-doped rGO nanosheets for microbial fuel cell applications. Sustain. Energy Fuels 2020, 4, 1454-1468. [CrossRef]

101. Tang, H.; Cai, S.; Xie, S.; Wang, Z.; Tong, Y.; Pan, M.; Lu, X. Metal-organic-framework-derived dual metaland nitrogen-doped carbon as efficient and robust oxygen reduction reaction catalysts for microbial fuel cells. Adv. Sci. 2020, 3, 1500265. [CrossRef]

102. Greenmana, G.J.; Santoro, C.; Serov, A.; Melhuish, C.; Atanassov, P.; Ieropoulos, I.A. Improved power and long- term performance of microbial fuel cell with Fe-N-C catalyst in air-breathing cathode. Energy 2018, 144, 1073-1079.

103. Erable, B.; Oliot, M.; Lacroix, R.; Bergel, A.; Serov, A.; Kodali, M.; Santoro, C.; Atanassov, P. Iron-nicarbazin derived platinum group metal-free electrocatalyst in scalable-size air-breathing cathodes for microbial fuel cells. Electrochim. Acta 2018, 277, 127-135. [CrossRef] [PubMed]

104. Liu, Y.; Fan, Y.S. Pyrolysis of iron phthalocyanine on activated carbon as highly efficient non noble metal oxygen reduction catalyst in microbial fuel cells. Chem. Eng. J. 2019, 361, 416-427. [CrossRef]

105. Jasinski, R. A new fuel cell cathode catalyst. Nature 1964, 201, 1212-1213. [CrossRef]

106. Zion, N.; Friedman, A.; Levy, N.; Elbaz, L. Bioinspired electrocatalysis of oxygen reduction reaction in fuel cells using molecular catalysts. Adv. Mater. 2018, 30, 1800406. [CrossRef] [PubMed]

107. Lei, H.; Liu, C.; Wang, Z.; Zhang, Z.; Zhang, M.; Chang, X.; Zhang, W.; Cao, R. Reactivity and Mechanism Studies of Hydrogen Evolution Catalyzed by Copper Corroles. ACS Catal. 2016, 6, 6429-6437. [CrossRef]

108. Raggio, M.; Mecheri, B.; Nardis, S.; D’Epifanio, A.; Licoccia, S.; Paolesse, R. Metallo-corroles supported on carbon nanostructures as oxygen reduction electrocatalysts in neutral media. Eur. J. Inorg. Chem. 2019, 44, 4760-4765. [CrossRef]

109. Shpilman, J.S.; Friedman, A.; Zion, N.; Levy, N.; Major, D.T.; Elbaz, L. Combined experimental and theoretical study of cobalt corroles as catalysts for oxygen reduction reaction. J. Phys. Chem. C 2019, 123, 30129-30136. [CrossRef]

110. Levy, N.; Shpilman, J.S.; Honig, H.C.; Major, D.T.; Elbaz, L. A surprising substituent effect in corroles on the electrochemical activation of oxygen reduction. Chem. Commun. 2017, 53, 12942-12945. [CrossRef]

111. Levy, N.; Mahammed, A.; Kosa, M.; Major, D.T.; Gross, Z.; Elbaz, L. Metallocorroles as nonprecious-metal catalysts for oxygen reduction. Angew. Chem. Int. Ed. 2015, 54, 14080-14084. [CrossRef] [PubMed]

112. Zagal, J.H.; Kruusenberg, I.; Tammeveski, K.; Recio, J.; Muñoz, K.; Venegas, R. Oxygen reduction on carbon-supported metallophthalocyanines and metalloporphyrins. Elsevier Encycl. Interfacial Chem. Electrochem. 2018, 812-819. [CrossRef]

113. Dong, G.; Huang, M.; Guan, L. Iron phthalocyanine coated on single-walled carbon nanotubes composite for the oxygen reduction reaction in alkaline media. Phys. Chem. Chem. Phys. 2012, 14, 2557-2559. [CrossRef] [PubMed]

114. Liu, D.; Long, Y.-T. Superior Catalytic Activity of Electrochemically Reduced Graphene Oxide Supported Iron Phthalocyanines toward Oxygen Reduction Reaction. ACS Appl. Mater. Interfaces 2015, 7, 24063-24068. [CrossRef] [PubMed]

115. Yang, J.; Toshimitsu, F.; Yang, Z.; Fujigaya, T.; Nakashima, N. Pristine carbon nanotube/iron phthalocyanine hybrids with a well-defined nanostructure show excellent efficiency and durability for oxygen reduction reaction. J. Mater. Chem. A 2013, 5, 1184-1191. [CrossRef]

116. Van Veen, J.A.R.; Colijn, H.A.; van Baar, J.F. On the effect of a heat treatment on the structure of carbon-supported metalloporphyrins and phthalocyanines. Electrochim. Acta 1998, 33, 801-804. [CrossRef]

117. Nguyen, M.-T.; Mecheri, B.; Iannaci, A.; D’Epifanio, A.; Licoccia, S. Iron/polyindole-based electrocatalysts to enhance oxygen reduction in microbial fuel cells. Electrochim. Acta 2016, 190, 388-395. [CrossRef]

118. Iannaci, A.; Mecheri, B.; D'Epifanio, A.; Elorri, M.J.L.; Liccocia, S. Iron-nitrogen-functionalized carbon as efficient oxygen reduction reaction electrocatalyst in microbial fuel cells. Int. J. Hydrog. Energy 2016, 41, 19637-19644. [CrossRef] 
119. Santoro, C.; Gokhale, A.; Mecheri, B.; D’Epifanio, A.; Licoccia, S.; Serov, A.; Artyushkova, K.; Atanassov, P. Design of iron (II) phthalocyanine-derived oxygen reduction electrocatalysts for high-power-density microbial fuel cells. ChemSusChem 2017, 10, 3243-3251. [CrossRef]

120. Osgood, H.; Devaguptapu, S.V.; Xu, H.; Cho, J.; Wu, G. Transition metal (Fe, Co, Ni, and Mn) oxides for oxygen reduction and evolution bifunctional catalysts in alkaline media. Nano Today 2016, 11, 601-625. [CrossRef]

121. Wang, Y.; Li, J.; Wei, Z. Transition-metal-oxide-based catalysts for the oxygen reduction reaction. J. Mater. Chem. A 2018, 6, 8194-8209. [CrossRef]

122. Goswami, C.; Kashyap Hazarika, K.; Bharali, P. Transition metal oxide nanocatalysts for oxygen reduction reaction. Mater. Sci. Energy Technol. 2018, 1, 117-128. [CrossRef]

123. Sun, M.; Liu, H.; Liu, Y.; Qu, J.; Li, J. Graphene-based transition metal oxide nanocomposites for the oxygen reduction reaction. Nanoscale 2015, 7, 1250-1269. [CrossRef] [PubMed]

124. Seonghee, K.; Kato, S.; Ishizaki, T.; Li, O.L.; Kang, J. Transition metal (Fe, Co, Ni) nanoparticles on selective amino-N-doped carbon as high-performance oxygen reduction reaction electrocatalyst. Nanomaterials 2019, 9, 742 .

125. Su, Y.; Zhu, Y.; Yang, X.; Shen, J.; Lu, J.; Zhang, X.; Chen, J.; Li, C. A highly efficient catalyst toward oxygen reduction reaction in neutral media for microbial fuel cells. Ind. Eng. Chem. Res. 2013, 52, 6076-6082. [CrossRef]

126. Li, X.; Hu, B.; Suib, S.; Lei, Y.; Li, B. Manganese dioxide as a new cathode catalyst in microbial fuel cells. J. Power Sources 2010, 195, 2586-2591. [CrossRef]

127. Gautam, R.K.; Bhattacharjee, H.; Mohan, S.V.; Verma, A. Nitrogen doped graphene supported $\alpha-\mathrm{MnO} 2$ nanorods for efficient ORR in a microbial fuel cell. RSC Adv. 2016, 6, 110091-110101. [CrossRef]

128. Farahani, F.S.; Mecheri, B.; Majidi, M.R.; Oliveira, M.A.C.; D’Epifanio, A.; Zurlo, F.; Placidi, E.; Arciprete, F.; Licoccia, S. MnOx-based electrocatalysts for enhanced oxygen reduction in microbial fuel cell air cathodes. J. Power Sources 2018, 390, 45-53. [CrossRef]

129. Farahani, F.S.; Mecheri, B.; Majidi, M.R.; Placidi, E.; D’Epifanio, A. Carbon-supported Fe/Mn-based perovskite-type oxides boost oxygen reduction in bioelectrochemical systems. Carbon 2019, 145, 716-724. [CrossRef]

130. Huang, Q.; Zhou, P.; Yang, H.; Zhu, L.; Wu, H. In situ generation of inverse spinel $\mathrm{CoFe}_{2} \mathrm{O}_{4}$ nanoparticles onto nitrogen-doped activated carbon for an effective cathode electrocatalyst of microbial fuel cells. Chem. Eng. J. 2017, 325, 466-473. [CrossRef]

131. Burkitt, R.; Whiffen, T.R.; Yu, E.H. Iron phthalocyanine and MnOx composite catalysts for microbial fuel cell applications. Appl. Catal. B Environ. 2016, 181, 279-288. [CrossRef]

132. Zhang, Y.; Deng, L.; Hu, H.; Qiao, Y.; Yuan, H.; Chen, D.; Chang, M.; Wei, H. Pomelo peel-derived, $\mathrm{N}$-doped biochar microspheres as an efficient and durable metal-free ORR catalyst in microbial fuel cells. Sustain. Energy Fuels 2020, 4, 1642-1653. [CrossRef]

133. Mao, K.; Zhang, W.; Dai, J.; Zeng, X.C. Carbon fragments as highly active metal-free catalysts for the oxygen reduction reaction: A mechanistic study. Nanoscale 2019, 11, 19422-19428. [CrossRef] [PubMed]

134. Zhong, K.; Li, M.; Yang, Y.; Zhang, H.; Zhang, B.; Tang, J.; Yan, J.; Su, M.; Yang, Z. Nitrogen-doped biochar derived from watermelon rind as oxygen reduction catalyst in air cathode microbial fuel cells. Appl. Energy 2019, 242, 516-525.

135. Liu, X.; Zhang, Y.; Li, Z.; Feng, R.; Zhang, Y. Characterization of corncob-derived biochar and pyrolysis kinetics in comparison with corn stalk and sawdust. Bioresour. Technol. 2014, 170, 76-82. [CrossRef]

136. Yuan, H.; Deng, L.; Qi, Y.; Kobayashi, N.; Tang, J. Nonactivated and activated biochar derived from bananas as alternative cathode catalyst in microbial fuel cells. Sci. World J. 2014, 2014, 1-8. [CrossRef] [PubMed]

137. Agrafioti, E.; Bouras, G.; Kalderis, D.; Diamadopoulos, E. Biochar production by sewage sludge pyrolysis. J. Anal. Appl. Pyrolysis 2018, 101, 72-78. [CrossRef]

138. Goldfarb, J.L.; Buessing, L.; Gunn, E.; Lever, M.; Billias, A.; Casoliba, E.; Schievano, A.; Adani, F. Novel integrated biorefinery for olive mill waste management: Utilization of secondary waste for water treatment. ACS Sustain. Chem. Eng. 2017, 5, 876-884. [CrossRef]

139. Goldfarb, J.L.; Dou, G.; Salari, M.; Grinstaff, M.W. Biomass-based fuels and activated carbon electrode materials: An integrated approach to green energy systems. ACS Sustain. Chem. Eng. 2017, 5, 3046-3054. [CrossRef] 
140. Hagemann, N.; Spokas, K.; Schmidt, H.-P.; Kägi, R.; Böhler, M.A.; Bucheli, T.D. Activated carbon, biochar and charcoal: Linkages and synergies across pyrogenic carbon's ABCs. Water 2018, 10, 182. [CrossRef]

141. Dhelipan, A.; Arunchander, A.; Sahu, A.K.; Kalpana, D. Activated carbon from orange peels as supercapacitor electrode and catalyst support for oxygen reduction reaction in proton exchange membrane fuel cell. J. Saudi Chem. Soc. 2017, 21, 487-494. [CrossRef]

142. Lv, Y.; Gan, L.; Liu, M.; Xiong, W.; Xua, Z.; Zhu, D.; Wright, D.S. A self-template synthesis of hierarchical porous carbon foams based on banana peel for supercapacitor electrodes. J. Power Sources 2012, 209, 152-157. [CrossRef]

143. Deng, L.-F.; Dong, G.; Cai, X.-X. Biochar derived from the inner membrane of passion fruit as cathode catalyst of microbial fuel cells in neutral solution. J. Fuel Chem. Technol. 2018, 46, 120-128.

144. Li, M.; Zhang, H.; Xiao, T.; Wang, S.; Zhang, B.; Chen, D.; Su, M.; Tang, J. Low-cost biochar derived from corncob as oxygen reduction catalyst in air cathode microbial fuel cells. Electrochim. Acta 2018, 283, 780-788. [CrossRef]

145. Chang, H.-C.; Gustave, W.; Yuan, Z.-F.; Xiao, Y.; Chen, Z. One-step fabrication of binder-free air cathode for microbial fuel cells by using balsa wood biochar. Environ. Technol. Innov. 2020, 18, 100615. [CrossRef]

146. Liu, X.; Zhou, Y.; Zhou, W.; Li, L.; Huang, S.; Chen, S. Biomass-derived heteroatoms-doped mesoporous carbon for efficient oxygen reduction in microbial fuel cells. Biosens. Bioelectron. 2017, 98, 350-356. [CrossRef]

147. Miran, W.; Nawaz, M.; Jang, J.; Lee, D.S. Conversion of orange peel waste biomass to bioelectricity using a mediator-less microbial fuel cell. Sci. Total Environ. 2016, 547, 197-205. [CrossRef]

148. Sciarria, T.P.; Tenca, A.; D’Epifanio, A.; Mecheri, B.; Merlino, G.; Barbato, M.; Borin, S.; Licoccia, S.; Garavaglia, V.; Adani, F. Using olive mill wastewater to improve performance in producing electricity from domestic wastewater by using single-chamber microbial fuel cell. Bioresour. Technol. 2013, 147, 246-253. [CrossRef]

149. Sciarria, T.P.; Costa de Oliveira, M.A.; Mecheri, B.; D’Epifanio, A.; Goldfarb, J.L.; Adani, F. Metal-free activated biochar as an oxygen reduction reaction catalyst in single chamber microbial fuel cells. J. Power Sources 2020, 462, 228183. [CrossRef]

150. Xue, H.; He, T.; Chabu, J.M.; Liu, J.; Wu, H.; Zheng, J.; Tan, M.; Ma, J.; Shen, R.; Deng, L.; et al. Iron single clusters anchored on $\mathrm{N}$-doped porous carbon as superior trace-metal catalysts toward oxygen reduction. Adv. Mater. Interfaces 2018, 5, 1701345. [CrossRef]

151. Shi, X.; Zhang, J.; Huang, T. The key roles of trace iron for nitrogen, sulfur dual-doped carbon nanospheres as high efficient oxygen reduction catalyst. J. Mater. Sci. 2018, 53, 1404-1413. [CrossRef]

152. Bhattacharyya, S.; Konkena, B.; Jayaramulu, K.; Schuhmann, W.; Maji, T.K. Synthesis of nano-porous carbon and nitrogen doped carbon dots from an anionic MOF: A trace cobalt metal residue in carbon dots promotes electrocatalytic ORR activity. J. Mater. Chem. A 2017, 5, 13573-13580. [CrossRef]

153. Ye, R.; Dong, J.; Wang, L.; Mendoza-Cruz, R.; Li, Y.; An, P.-F.; Yacamán, M.J.; Yakobson, B.I.; Chen, D.; Tour, J.M. Manganese deception on graphene and implications in catalysis. Carbon 2018, 132, 623-631. [CrossRef] [PubMed]

154. Masa, J.; Xia, W.; Muhler, M.; Schuhmann, W. On the role of metals in nitrogen-doped carbon electrocatalysts for oxygen reduction. Angew. Chem. Int. Ed. 2015, 54, 10102-10120. [CrossRef] [PubMed]

(C) 2020 by the authors. Licensee MDPI, Basel, Switzerland. This article is an open access article distributed under the terms and conditions of the Creative Commons Attribution (CC BY) license (http://creativecommons.org/licenses/by/4.0/). 